\title{
Modeling the impact of chlorine emissions from coal combustion and prescribed waste incineration on tropospheric ozone formation in China
}

\author{
Yiming Liu ${ }^{1,2}$, Qi Fan ${ }^{1,2}$, Xiaoyang Chen ${ }^{1,2}$, Jun Zhao ${ }^{1,2}$, Zhenhao Ling ${ }^{1,2}$, Yingying Hong ${ }^{3}$, Weibiao Li ${ }^{1,2}$, \\ Xunlai Chen ${ }^{4}$, Mingjie Wang ${ }^{4}$, and Xiaolin $\mathrm{Wei}^{4}$ \\ ${ }^{1}$ School of Atmospheric Sciences, Sun Yat-sen University, Guangzhou, 510275, China \\ ${ }^{2}$ Guangdong Province Key Laboratory for Climate Change and Natural Disaster Studies, Guangzhou, 510275, China \\ ${ }^{3}$ Guangdong Ecological Meteorology Center, Guangzhou, 510640, China \\ ${ }^{4}$ Shenzhen Key Laboratory of Severe Weather in South China, Shenzhen, 518040, China
}

Correspondence: Qi Fan (eesfq@mail.sysu.edu.cn) and Jun Zhao (zhaojun23@mail.sysu.edu.cn)

Received: 9 September 2017 - Discussion started: 6 November 2017

Revised: 5 January 2018 - Accepted: 9 January 2018 - Published: 26 February 2018

\begin{abstract}
Chlorine radicals can enhance atmospheric oxidation, which potentially increases tropospheric ozone concentration. However, few studies have been done to quantify the impact of chlorine emissions on ozone formation in China due to the lack of a chlorine emission inventory used in air quality models with sufficient resolution. In this study, the Anthropogenic Chlorine Emissions Inventory for China (ACEIC) was developed for the first time, including emissions of hydrogen chloride $(\mathrm{HCl})$ and molecular chlorine $\left(\mathrm{Cl}_{2}\right)$ from coal combustion and prescribed waste incineration (waste incineration plant). The $\mathrm{HCl}$ and $\mathrm{Cl}_{2}$ emissions from coal combustion in China in 2012 were estimated to be 232.9 and $9.4 \mathrm{Gg}$, respectively, while $\mathrm{HCl}$ emission from prescribed waste incineration was estimated to be $2.9 \mathrm{Gg}$. Spatially the highest emissions of $\mathrm{HCl}$ and $\mathrm{Cl}_{2}$ were found in the North China Plain, the Yangtze River Delta, and the Sichuan Basin. Air quality model simulations with the Community Multiscale Air Quality (CMAQ) modeling system were performed for November 2011, and the modeling results derived with and without chlorine emissions were compared. The magnitude of the simulated $\mathrm{HCl}, \mathrm{Cl}_{2}$ and $\mathrm{ClNO}_{2}$ agreed reasonably with the observation when anthropogenic chlorine emissions were included in the model. The inclusion of the ACEIC increased the concentration of fine particulate $\mathrm{Cl}^{-}$, leading to enhanced heterogeneous reactions between $\mathrm{Cl}^{-}$and $\mathrm{N}_{2} \mathrm{O}_{5}$, which resulted in the higher production of $\mathrm{ClNO}_{2}$. Photolysis of $\mathrm{ClNO}_{2}$ and $\mathrm{Cl}_{2}$ in the morning and the reaction of $\mathrm{HCl}$ with $\mathrm{OH}$ in the afternoon produced
\end{abstract}

chlorine radicals which accelerated tropospheric oxidation. When anthropogenic chlorine emissions were included in the model, the monthly mean concentrations of fine particulate $\mathrm{Cl}^{-}$, daily maximum $1 \mathrm{~h} \mathrm{ClNO}_{2}$, and $\mathrm{Cl}$ radicals were estimated to increase by up to about $2.0 \mu \mathrm{g} \mathrm{m}^{-3}, 773 \mathrm{pptv}$, and $1.5 \times 10^{3}$ molecule $\mathrm{cm}^{-3}$ in China, respectively. Meanwhile, the monthly mean daily maximum $8 \mathrm{~h} \mathrm{O}_{3}$ concentration was found to increase by up to $2.0 \mathrm{ppbv}(4.1 \%)$, while the monthly mean $\mathrm{NO}_{x}$ concentration decreased by up to $0.5 \mathrm{ppbv}(6.1 \%)$. The anthropogenic chlorine emissions potentially increased the $1 \mathrm{~h} \mathrm{O}_{3}$ concentration by up to $7.7 \mathrm{ppbv}$ in China. This study highlights the need for the inclusion of anthropogenic chlorine emission in air quality modeling and demonstrated its importance in tropospheric ozone formation.

\section{Introduction}

Chlorine radicals $(\mathrm{Cl})$ are highly reactive, playing a significant role in the oxidative chemistry of the troposphere (Faxon and Allen, 2013; Young et al., 2014). Similar to hydroxyl radicals $(\mathrm{OH})$, chlorine radicals can oxidize volatile organic compounds (VOCs), which potentially enhance ozone formation. In general, chlorine radicals are more reactive towards most of the VOCs than hydroxyl radicals. The reaction rate constants of chlorine radicals with many alkanes, aromatics, alcohols, and ethers range typically between 1 and 
2 orders of magnitude greater than the corresponding values for hydroxyl radicals (Aschmann and Atkinson, 1995; Nelson et al., 1990; Wang et al., 2005). Hence, the high reaction rates make the chlorine radicals competitive with the $\mathrm{OH}$ radicals though the concentration of chlorine radicals is an order of magnitude or more lower than that of hydroxyl radicals (Wingenter et al., 1999). Chlorine radicals can be produced from photodissociation and oxidation of many of the most common chlorinated organic species, but these reaction rates are generally not fast enough to contribute significantly to the concentrations of chlorine radicals. $\mathrm{ClNO}_{2}$, $\mathrm{Cl}_{2}$, and $\mathrm{HCl}$ are dominant primary chlorine radical sources. Riedel et al. (2012) reported that the relative contributions to $\mathrm{Cl}$ radicals from $\mathrm{ClNO}_{2}, \mathrm{Cl}_{2}$, and $\mathrm{HCl}$ were approximately 45,10 , and $45 \%$, respectively, in the Los Angeles regions by using a simple box model with local observation. While photolysis of $\mathrm{ClNO}_{2}$ and $\mathrm{Cl}_{2}$ occurs in the morning, the reaction of $\mathrm{HCl}$ with $\mathrm{OH}$ occurs in the afternoon. The reactions are shown as follows:

$$
\begin{aligned}
& \mathrm{ClNO}_{2}(\mathrm{~g})+h v \rightarrow \mathrm{Cl}(\mathrm{g})+\mathrm{NO}_{2}(\mathrm{~g}) \\
& \mathrm{Cl}_{2}(\mathrm{~g})+h v \rightarrow 2 \mathrm{Cl}(\mathrm{g}) \\
& \mathrm{HCl}(\mathrm{g})+\mathrm{OH} \rightarrow \mathrm{Cl}(\mathrm{g})+\mathrm{H}_{2} \mathrm{O} .
\end{aligned}
$$

In the troposphere, nitryl chloride is formed primarily by the heterogeneous reaction between $\mathrm{N}_{2} \mathrm{O}_{5}$ and $\mathrm{Cl}^{-}$(Eqs. 4-7) (Bertram and Thornton, 2009; Roberts et al., 2009), while the latter reactant $\mathrm{Cl}^{-}$is the major product of $\mathrm{HCl}$ neutralization (Seinfeld and Pandis, 1998; Pio and Harrison, 1987). Therefore, identification of emission sources and quantification of their contributions to ambient $\mathrm{HCl}$ levels are of critical importance for the estimation of the abundance of $\mathrm{ClNO}_{2}$ and/or $\mathrm{Cl}$ radicals.

$$
\begin{aligned}
& \mathrm{N}_{2} \mathrm{O}_{5}(\mathrm{~g}) \leftrightarrow \mathrm{NO}_{3}^{-}(\mathrm{aq})+\mathrm{NO}_{2}^{+}(\mathrm{aq}) \\
& \mathrm{NO}_{3}^{-}(\mathrm{aq})+\mathrm{H}^{+}(\mathrm{aq}) \rightarrow \mathrm{HNO}_{3}(\mathrm{~g}) \\
& \mathrm{NO}_{2}^{+}(\mathrm{aq})+\mathrm{H}_{2} \mathrm{O} \rightarrow \mathrm{HNO}_{3}(\mathrm{~g})+\mathrm{H}^{+} \\
& \mathrm{NO}_{2}^{+}(\mathrm{aq})+\mathrm{Cl}^{-}(\mathrm{aq}) \rightarrow \mathrm{ClNO}_{2}(\mathrm{~g})
\end{aligned}
$$

The major sources of tropospheric $\mathrm{HCl}$ in the atmosphere include natural sources from sea salt (Keene et al., 1999) and biomass burning (Andreae et al., 1996) and anthropogenic sources from coal combustion and waste incineration (McCulloch et al., 1999). The global annual emission rates of $\mathrm{HCl}$ from sea salt and biomass burning were estimated to be $50 \mathrm{Tg} \mathrm{Cl} \mathrm{yr}^{-1}$ (Graedel and Keene, 1995; Keene et al., 1999) and $6 \mathrm{Tg} \mathrm{Cl} \mathrm{yr}^{-1}$ (Lobert et al., 1999), respectively. Although the emission rates from natural sources are much higher than their anthropogenic counterparts, they are relatively constant and well estimated. The corresponding anthropogenic emission rates from coal combustion and waste incineration were previously estimated to be 4.6 and $2 \mathrm{Tg} \mathrm{Cl} \mathrm{yr}^{-1}$, respectively (McCulloch et al., 1999). Waste incinerations include open waste incineration (the uncontrolled emissions from both residential and dump waste burning) and prescribed waste incineration (the emission from waste incineration plant). The contribution of open waste incineration to $\mathrm{HCl}$ was estimated to be $1 \mathrm{Tg} \mathrm{yr}^{-1}$ in China (Wiedinmyer et al., 2014), while that of prescribed waste was unknown, awaiting further investigation.

Molecular chlorine $\left(\mathrm{Cl}_{2}\right)$ is another important precursor of $\mathrm{Cl}$ radicals. However, only a few studies on its emissions are available in the literature. Chang et al. (2002) compiled an emission inventory of $\mathrm{Cl}_{2}$ and $\mathrm{HOCl}$ for Houston and estimated an emission of about $10^{4} \mathrm{~kg}$ per day in total in southeast Texas. Deng et al. (2014) collected flue gas samples from six pulverized coal boiler units of four coal-fired power plants in China and found that about $3.6 \%$ of chlorine in coal could release in the form of gaseous $\mathrm{Cl}_{2}$ during combustion. Measurements of $\mathrm{Cl}_{2}$ in urban environment are also sparse, although some were made in marine air and at polar sunrise in the past (Finley and Saltzman, 2008; Lawler et al., 2011; Spicer et al., 2002; Impey et al., 1997).

Once the chlorine emission inventory was constructed, the effects of the chlorine radicals on tropospheric ozone formation can be assessed with air quality models by incorporating the emission inventory. For example, the simulation results of the comprehensive air quality model with extensions (CAMx) found that the emissions of $\mathrm{HCl}$ and $\mathrm{HOCl}$ could increase $1 \mathrm{~h}$ averaged $\mathrm{O}_{3}$ concentration by $70 \mathrm{ppbv}$ in very localized areas during morning hours (Chang and Allen, 2006). Furthermore, Sarwar and Bhave (2007) estimated the effect of chlorine emission on ozone formation in the eastern United States through model simulations. They found that the monthly mean daily maximum $1 \mathrm{~h}$ ozone mixing ratios could be enhanced by up to 3 ppbv in the Houston area when the anthropogenic emissions of $\mathrm{Cl}_{2}$ and $\mathrm{HOCl}$ and the chlorine from sea salt aerosols were considered.

However, the role of the oxidation of hydrocarbons by $\mathrm{Cl}$ radicals on $\mathrm{O}_{3}$ formation is still unclear in China, which is mainly due to the lack of an up-to-date anthropogenic chlorine emission inventory. For example, the most widely used emission inventory, the Multi-resolution Emission Inventory for China (MEIC), which was developed by Tsinghua University (http://www.meicmodel.org), does not include $\mathrm{HCl}$ and $\mathrm{Cl}_{2}$ emissions. In addition, though a reactive chlorine emission inventory (RCEI) in 1990 from coal combustion and waste burning was developed by McCulloch et al. (1999), covering each country all around the world with a resolution of $1^{\circ} \times 1^{\circ}$, it could not represent the present situation in China due to the fast industrial and economic development in recent years. Li et al. (2016) applied the RCEI in the WRF-Chem (Weather Research and Forecasting coupled with Chemistry) model to simulate the air quality in the Pearl River Delta of China. Results from sensitivity experiments showed that the simulated particulate $\mathrm{Cl}^{-}$and $\mathrm{ClNO}_{2}$ concentrations were highly sensitive to the chlorine emissions. There is hence a need to develop an up-to-date anthropogenic chlorine emission inventory in China in order to better model $\mathrm{ClNO}_{2}$ production and to quantify its effect on atmospheric chemistry and air quality. Development of an anthropogenic 
chlorine emission inventory can also help policymakers to propose better strategies in air quality management.

In this study, the Anthropogenic Chlorine Emission Inventory for China (ACEIC) was developed for the first time to include the emissions of hydrogen chloride and molecular chlorine from coal combustion and prescribed waste incineration in China. This emission inventory was then applied to the Community Multiscale Air Quality (CMAQ) modeling system to evaluate the effects of chlorine emissions on photochemical $\mathrm{O}_{3}$ formation through sensitivity analysis. Simulations were performed for November 2011 and the results derived with and without the ACEIC were compared. Section 2 describes the development of chlorine emissions in China. Section 3 presents the model simulation to quantify the impact of these anthropogenic chlorine emissions on atmospheric oxidation and ozone formation.

\section{Chlorine emission inventory for China}

\subsection{Emission from coal combustion}

\subsubsection{Coal consumption database}

Coal consumption data are needed for estimating the chlorine emissions. We selected 2012 as the base year of this emission inventory. The database of coal consumptions was constructed based on the data from the China Energy Statistical Yearbook (CESY, National Bureau of Statistics, 2013), which include 31 provinces, municipalities, and autonomous regions. A zero value of coal consumption in Tibet was assumed in the database due to unavailable data in the yearbook. In addition, coal combustion in Hong Kong and Taiwan were taken from International Energy Agency energy statistics (IEA, 2012) and were included in the database. Hence a total of 33 regions were included in this inventory (Table 1). Similar to the classification method used in the MEIC emission inventory, in the ACEIC we classified the coal consumption from the CESY into four economic sectors according to their characteristics: (1) power plant sector, including electricity plants, heat plants, and combined heat and power (CHP) plants; (2) industrial sector, including iron and steel, nonferrous metals, and other categories covering large-scale combustion processes; (3) residential sector, including personal consumption in both urban and rural regions; (4) other sector, including agriculture, forestry, animal husbandry, fishery, water conservancy, construction, transport, storage, post, wholesale, retail trade, hotel, restaurants, and other consumption. Columns $2-5$ in Table 1 list the coal consumption among different categories in different provinces (or regions), along with various chlorine content in coal as discussed in the following section. In 2012, a total of 3.6 million tons of coal were consumed, with Shandong ( 0.3 million tons) being the highest consumer and Hainan the lowest (about $9000 \mathrm{t}$, Tibet not included).

\subsubsection{Chlorine contents in coal}

Chlorine is enriched in coal to some extent and is volatilized during the coal combustion process. The chlorine content in coal is essential for emission estimation and it can vary from region to region. It was reported that the chlorine content in coal in China ranged from 50 to $500 \mu \mathrm{g} \mathrm{g}^{-1}$ with an average value of $\sim 220 \mathrm{\mu g} \mathrm{g}^{-1}$ (Tang and Chen, 2002), lower than most other countries. Meanwhile, average chlorine contents between 200 and $300 \mu \mathrm{g} \mathrm{g}^{-1}$ in China were also reported ( $\mathrm{Lu}$, 1996; Zhao et al., 1999). Chen (2010) reported a wide range of chlorine content (39-637 $\mu \mathrm{g} \mathrm{g}^{-1}$ ) with an average chlorine content of $280 \mathrm{\mu g} \mathrm{g}^{-1}$, falling within the values mentioned above. In this study, we chose chlorine contents reported from Chen (2010) to estimate chlorine emissions in all regions except Shanghai, Tianjin, Hong Kong, and Taiwan. For these regions where chlorine contents are not listed in the literature, we estimated the chlorine emissions using the average chlorine content $\left(280 \mu \mathrm{g} \mathrm{g}^{-1}\right)$ in China according to Chen (2010).

Some of the coals consumed in China were imported from other countries which might have different chlorine contents. According to the report of the China Energy Statistical Yearbook (CESY, National Bureau of Statistics, 2013), the total amount of coals imported into China was $288 \mathrm{Tg}$ and the total coal consumption in China was $3526 \mathrm{Tg}$ in 2012. Over $91 \%$ of the coals were domestically produced in China. It is hence concluded that the different chlorine content of the imported coals has a minor influence on the estimation of chlorine emission in China. However, it is difficult to evaluate the extent of this influence. Hence, we estimated the chlorine emission from coal combustion in China using the chlorine content of coal from domestic sources and did not take the different chlorine content of the imported coals into account.

\subsubsection{Chlorine emission factors}

Chlorine emission factors from coal combustion vary with boilers and removal facilities. Table 2 summarizes the chlorine emission factors depending on the combination of boiler types and pollution control technologies in coal combustion (Jiang et al., 2005). This combination can vary significantly from one sector to another.

The net emission factors (EFs) were estimated by the following Eq. (8):

$$
\mathrm{EF}_{i, j}=c_{i} \times \sum_{k}\left(R_{j, k} \times X_{j, k} \times\left(1-\eta_{d_{j, k}}\right) \times\left(1-\eta_{s_{j, k}}\right)\right),
$$

where $i$ represents the province (municipality, autonomous region), $j$ represents the economic sector, $k$ represents the energy allocation type (type of boiler and control device combination), $c$ represents chlorine contents in coal, $R$ is the chlorine release rate, $X$ is the fraction of energy for a sector (energy allocation ratio), $\eta_{\mathrm{d}}$ is the removal efficiency of dust-removal facilities, and $\eta_{\mathrm{s}}$ is the removal efficiency of 


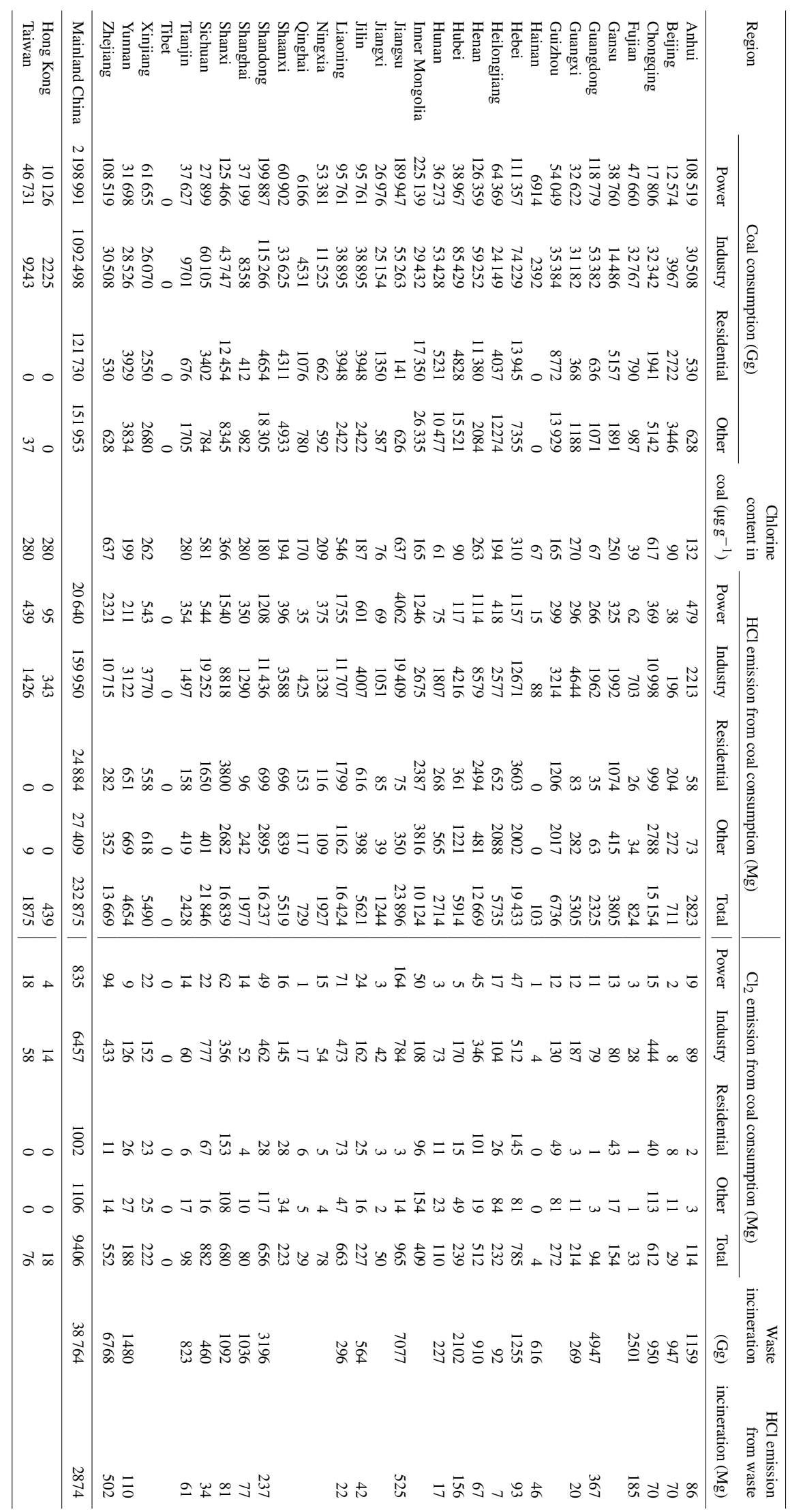

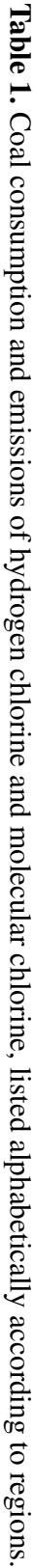


Table 2. Emission factors of chlorine from coal combustion in China.

\begin{tabular}{|c|c|c|c|c|c|c|}
\hline Economic sector & Boiler type & Pollution control technology & $\begin{array}{l}\text { Energy } \\
\text { allocation } \\
\text { ratio }(\%)^{\mathrm{a}}\end{array}$ & $\begin{array}{l}\text { Chlorine } \\
\text { release } \\
\text { rate }(\%)\end{array}$ & $\begin{array}{l}\text { Removal efficiency } \\
\text { from dust-removal } \\
\text { facilities }(\%)\end{array}$ & $\begin{array}{l}\text { Removal efficiency } \\
\text { from sulfate-removal } \\
\text { facilities }(\%)\end{array}$ \\
\hline \multirow[t]{5}{*}{ Power plant } & Pulverized coal boiler & Cottrell & 43 & $98.5^{\mathrm{b}}$ & $5.1^{\mathrm{b}}$ & $95.5^{\mathrm{b}}$ \\
\hline & Pulverized coal boiler & Bag-type dust remover & 43 & $98.5^{\mathrm{b}}$ & $10.4^{\mathrm{b}}$ & $95.5^{\mathrm{b}}$ \\
\hline & Pulverized coal boiler & Wet-type dust remover & 6 & $98.5^{\mathrm{b}}$ & $60.0^{\mathrm{c}}$ & $95.5^{\mathrm{b}}$ \\
\hline & Grate furnace & Wet-type dust remover & 7 & $99^{\mathrm{e}}$ & $60.0^{c}$ & $95.5^{\mathrm{b}}$ \\
\hline & Grate furnace & Mechanical dust collector & 1 & $99^{\mathrm{e}}$ & $25^{f}$ & $95.5^{\mathrm{b}}$ \\
\hline \multirow[t]{4}{*}{ Industry } & Grate furnace & Wet-type dust remover & 29 & $99^{\mathrm{e}}$ & $60.0^{c}$ & 0 \\
\hline & Grate furnace & Mechanical dust collector & 58 & $99^{\mathrm{e}}$ & $25^{f}$ & 0 \\
\hline & Grate furnace & No & 4 & $99^{\mathrm{e}}$ & 0 & 0 \\
\hline & Fluidized bed boiler & Wet-type dust remover & 9 & $99.6^{\mathrm{d}}$ & $60.0^{\mathrm{c}}$ & 0 \\
\hline \multirow[t]{3}{*}{ Residential } & Traditional stove & No & 19 & $94^{\mathrm{g}}$ & 0 & 0 \\
\hline & Reinforced stove & No & 41 & $94^{\mathrm{g}}$ & 0 & 0 \\
\hline & Tea bath & No & 4 & $94^{\mathrm{g}}$ & 0 & 0 \\
\hline Other & Grate furnace & No & 100 & $99^{\mathrm{e}}$ & 0 & 0 \\
\hline
\end{tabular}

${ }^{a}$ From Jiang et al. (2005). ${ }^{b}$ From Deng et al. (2014). ${ }^{c}$ From Jiang et al. (2004). ${ }^{d}$ From Lopez-Vilarino et al. (2003). ${ }^{e}$ From Ruud Meij, personal communication, 1991.

${ }^{\mathrm{f}}$ From Mei et al. (2006). ${ }^{\mathrm{g}}$ From Iapalucci et al. (1969).

sulfate-removal facilities. The chlorine emission factors in power plant, industry, residential, and other categories were calculated based on the parameters given in Tables 1 and 2 . They were then applied to estimate the $\mathrm{HCl}$ and $\mathrm{Cl}_{2}$ emissions from coal combustion.

\subsubsection{Development of the emission inventory}

The $\mathrm{HCl}$ and $\mathrm{Cl}_{2}$ emissions ( $E \mathrm{~s}$ ) from coal combustion were estimated as follows:

$E_{i, j}=M_{i, j} \times \mathrm{EF}_{i, j} \times \rho \times \frac{1}{\mathrm{MM}}$,

where $M$ represents coal consumption, $\mathrm{MM}$ denotes the ratios of the molar mass of chlorine atom to the molecular weight of $\mathrm{HCl}$ and $\mathrm{Cl}_{2}\left(35.5 / 36.5\right.$ for $\mathrm{HCl}$ and 1 for $\left.\mathrm{Cl}_{2}\right)$, and $\rho$ is the chlorine proportion of $\mathrm{HCl}$ and $\mathrm{Cl}_{2}$ in emitted flue gas. The flue gas contains chlorine species in the form of particulate $\mathrm{Cl}^{-}$and gaseous $\mathrm{HCl}$ and $\mathrm{Cl}_{2}$, which were formed through chemical transformation during coal combustion. An average chlorine proportion of about 86.3 and $3.6 \%$ was reported respectively for $\mathrm{HCl}$ and $\mathrm{Cl}_{2}$ in the flue gas samples, which were collected from six pulverized coal boiler units in four coal-fired power plants in China (Deng et al., 2014). We adopted this $\rho$ (86.3 and $3.6 \%$ respectively for $\mathrm{HCl}$ and $\mathrm{Cl}_{2}$ ) when calculating $\mathrm{HCl}$ and $\mathrm{Cl}_{2}$ emissions. Similar procedures were followed to estimate chlorine emissions in Hong Kong and Taiwan. Table 1 lists the calculated $\mathrm{HCl}$ and $\mathrm{Cl}_{2}$ emissions from coal combustion in each region (columns 7-11 for $\mathrm{HCl}$ and columns $12-16$ for $\mathrm{Cl}_{2}$ ).

We employed the same resolution $\left(0.25^{\circ} \times 0.25^{\circ}\right)$ as the one used in the MEIC for the meshed grid to develop the ACEIC. The $\mathrm{HCl}$ and $\mathrm{Cl}_{2}$ emissions from each economic sector were spatially allocated into the center of each grid cell. To allocate the chlorine emissions from power plants, a database of the location of each point source was needed. We constructed the database following the procedures below: the chlorine emissions in each grid cell were determined using the emissions of chlorine in the region, multiplied by a ratio of $\mathrm{SO}_{2}$ emissions from power plants in MIX (an Asian anthropogenic emission inventory) in each grid cell to the total emissions of $\mathrm{SO}_{2}$ in the region. MIX was developed for the year 2010 to support the Model Intercomparison Study for Asia Phase III (MICS-Asia III) and the Task Force on Hemispheric Transport of Air Pollution (TF HTAP) (Li et al., 2015). MEIC emission was included in MIX. MIX data had five categories: power plant, industry, residential, transport and agriculture. In ACEIC, the locations and relative amount of chlorine emissions from power plants were assumed to be the same as those of $\mathrm{SO}_{2}$ emissions from the power plants in MIX, though this hypothesis might lead to a small uncertainty. In this way, the spatial distributions of emissions of $\mathrm{HCl}$ and $\mathrm{Cl}_{2}$ from coal combustion of power plants were then determined. Chlorine emissions from other sectors were spatially allocated based on population in 2012. The chlorine emissions in each grid cell were obtained using the chlorine emissions in the region, multiplied by the ratio of population in each grid cell to the total population in the region. The spatial distributions of $\mathrm{HCl}$ and $\mathrm{Cl}_{2}$ emissions from coal combustion of power plant, industry, residential, and others are shown in Figs. S1 and S2 in the Supplement. The chlorine emission of each sector in eastern China was higher than that in western China. 


\subsection{Emission from prescribed waste incineration}

\subsubsection{Prescribed waste incineration database}

Table 1 also lists the waste incineration from garbage disposal incinerators in each province/city from the China Urban-Rural Construction Statistical Yearbook (CURCSY, National Bureau of Statistics, 2012), which was used to estimate chlorine emissions from prescribed waste incineration. Note that the emissions of chlorine were calculated only for the regions with garbage disposal incinerators (a total of 22 regions in this study). The information (location and daily capacity) on the garbage disposal incinerators was obtained from the Information Platform for Municipal Solid Waste Incineration (www.waste-cwin.org).

\subsubsection{The $\mathrm{HCl}$ emission factor for prescribed waste incineration}

Domestic waste contains chlorine in materials such as vegetable matter, paper, plastic, dry cell batteries, and salt (Lightowlers and Cape, 1988). The chlorine content of municipal waste is $0.5 \mathrm{wt} \%$ on average. An unabated emission factor of $2.2 \mathrm{~g} \mathrm{HCl} \mathrm{kg}^{-1}$ for municipal solid waste was reported by Emmel et al. (1989), lower than that for ordinary household waste $\left(3.5 \mathrm{~g} \mathrm{HCl} \mathrm{kg}^{-1}\right.$, D. Holland, personal communication, 1991). We adopted the former value $\left(2.2 \mathrm{~g} \mathrm{HCl} \mathrm{kg}^{-1}\right)$ when estimating the $\mathrm{HCl}$ emission from prescribed waste incineration. The $\mathrm{Cl}_{2}$ emission from prescribed waste incineration was not included due to unavailable data from the literature.

The net emission factor (EF) for prescribed waste incineration was estimated according to the following Eq. (10):

$\mathrm{EF}=\mathrm{EF}_{\mathrm{raw}} \times\left(1-\eta_{\mathrm{d}}\right) \times\left(1-\eta_{\mathrm{s}}\right)$,

where $\mathrm{EF}_{\text {raw }}$ is the unabated emission factor $\left(2.2 \mathrm{~g} \mathrm{~kg}^{-1}\right)$ and $\eta_{\mathrm{d}}$ and $\eta_{\mathrm{s}}$ are the chlorine removal efficiency of dust-removal facilities and sulfate-removal facilities, respectively. We assumed that the control technology of garbage disposal incinerator was similar to the coal combustion of a power plant, and we hence used the average values of $\eta_{\mathrm{s}}$ and $\eta_{\mathrm{d}}$ data for the power plant sector in Table 2 to yield the $\mathrm{HCl}$ emission factor.

\subsubsection{Development of the emission inventory}

The $\mathrm{HCl}$ emission $(E)$ for prescribed waste incineration were estimated as follows:

$E_{i}=M_{i} \times \mathrm{EF}$

where $i$ represents the province (municipality, autonomous region) and $M$ denotes the amount of prescribed waste incineration. The estimated $\mathrm{HCl}$ emissions from prescribed waste incineration in each region are listed in Table 1.
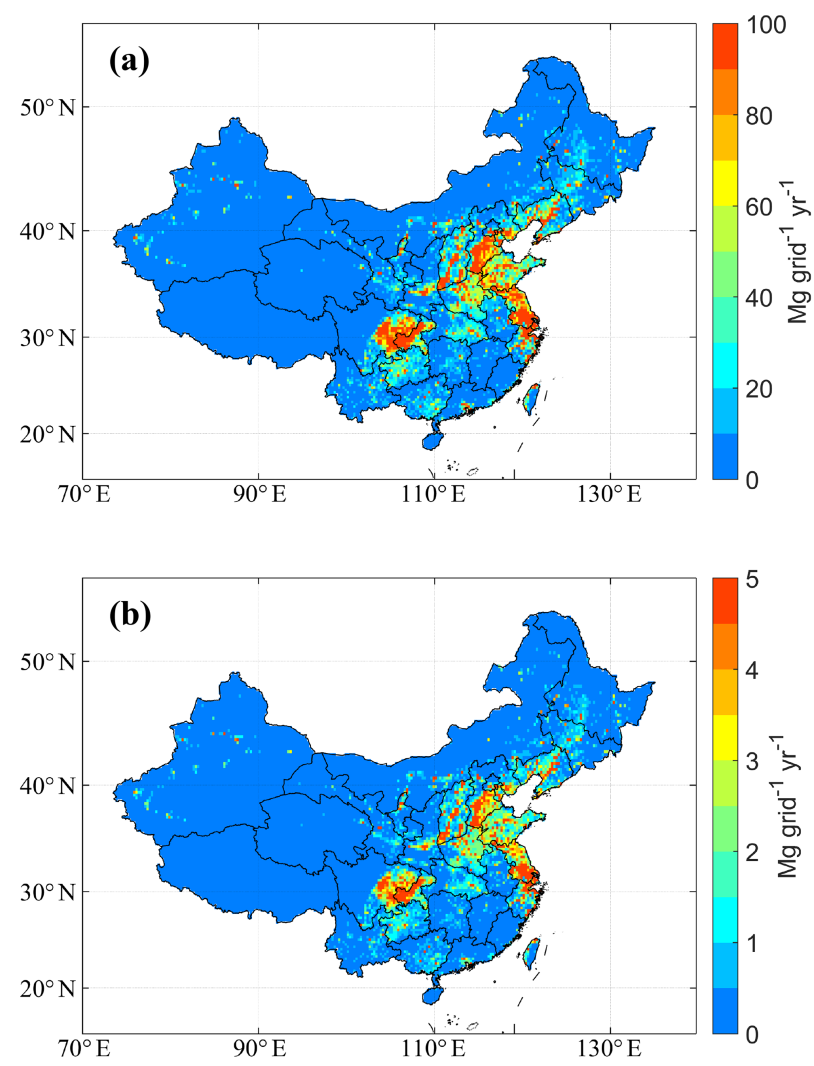

Figure 1. Spatial distribution of the emissions of hydrogen chloride (a) and molecular chlorine (b) in the ACEIC.

The $\mathrm{HCl}$ emission at each garbage disposal incinerator was obtained using the emission in the region, multiplied by the ratio of the daily capacity of each waste incineration plant to the total daily capacity of all plants in the region (Table 1). The $\mathrm{HCl}$ emissions at all the garbage disposal incinerators were then merged into a $0.25^{\circ} \times 0.25^{\circ}$ grid cell. The results show that high emissions from prescribed waste burning could be seen around the coastal region of eastern China (Fig. S3).

\subsection{The anthropogenic chlorine emission inventory for China}

\subsubsection{The $\mathrm{HCl}$ and $\mathrm{Cl}_{2}$ emissions}

The ACEIC developed in this study included $\mathrm{HCl}$ and $\mathrm{Cl}_{2}$ emissions from coal combustion and $\mathrm{HCl}$ emissions from prescribed waste incineration. Table 1 shows the chlorine emissions of all the regions in China, along with Hong Kong and Taiwan. The $\mathrm{HCl}$ and $\mathrm{Cl}_{2}$ emissions from coal combustion in China in 2012 were estimated to be 232.9 and $9.4 \mathrm{Gg}$, respectively, and $\mathrm{HCl}$ emissions from prescribed waste burning were estimated to be $2.9 \mathrm{Gg}$. Figure $1 \mathrm{a}$ and $\mathrm{b}$ show the spatial distribution of the total $\mathrm{HCl}$ and $\mathrm{Cl}_{2}$ emissions, respectively, where similar patterns were found, although in 


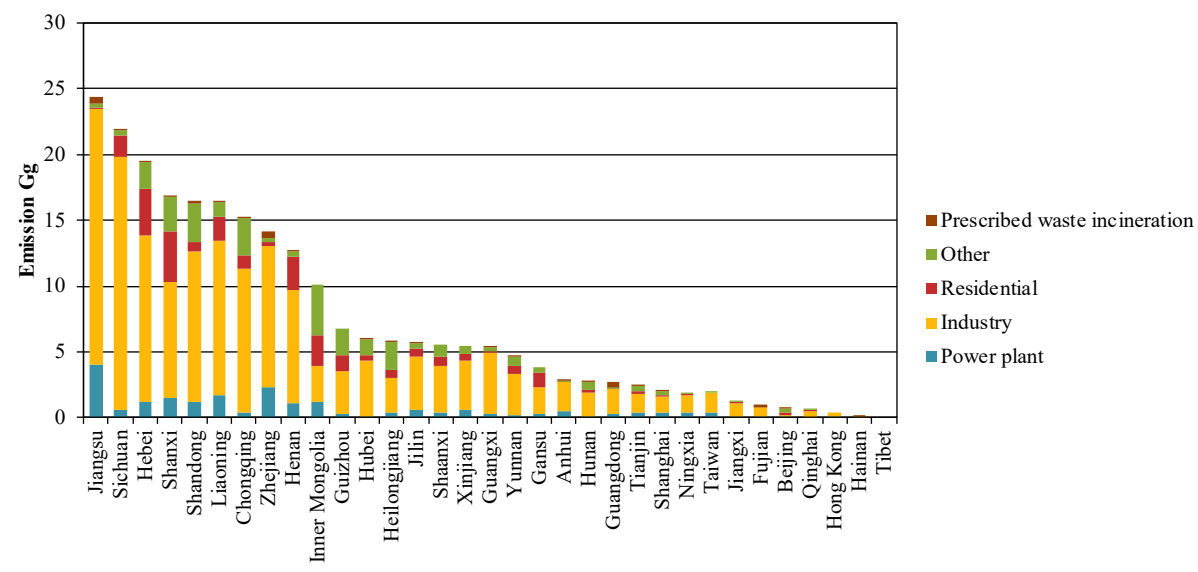

Figure 2. The $\mathrm{HCl}$ emission in the study region in 2012 from four economic sectors of coal combustion and from prescribed waste incineration.

general the $\mathrm{HCl}$ emission is almost 20 times higher than that of the $\mathrm{Cl}_{2}$ emission. The North China Plain, the Yangtze River Delta (YRD), and the Sichuan Basin contributed spatially high chlorine emissions. The highest $\mathrm{HCl}$ emission was found in Jiangsu, followed by Sichuan and Hebei provinces (Fig. 2). Chlorine emissions were relatively low in South China, including Guangdong, Hunan, Fujian, Jiangxi, and Hainan, probably due to the low chlorine contents in coal used in those regions. The $\mathrm{HCl}$ emission from industry contributed to as high as $68 \%$ of the total emissions, followed by others $(12 \%)$, residential $(10 \%)$, power plant $(9 \%)$, and prescribed waste incineration (1\%). Many industrial processes (e.g., iron and steel processing, nonferrous metals processing, cement production) that need coal burning are included in the industrial sector, leading to the highest source of $\mathrm{HCl}$.

\subsubsection{Comparison with other chlorine emission}

The RCEI developed by McCulloch et al. (1999) was the only emission inventory for chlorine that included China, containing the chlorine emitted globally from coal combustion and waste incineration in 1990. The ACEIC developed in this study made progress in four ways based on the RCEI. (1) The ACEIC provides a more comprehensive database of coal combustion and prescribed waste incineration in China. The data in each province/city in China were taken from the CESY and the CURCSY in this study, which were more detailed than those in the RCEI that were from IEA energy statistics and only included the total amount of coal consumption in China. (2) The ACEIC has a higher resolution $\left(0.25^{\circ} \times 0.25^{\circ}\right)$ than the RCEI $\left(1^{\circ} \times 1^{\circ}\right)$, providing a higher spatial resolution for regional air quality modeling. (3) There are more emission factors. When estimating emission factors, the ACEIC included the removal rates of chlorine from dust-removal facilities and sulfate-removal facilities in China, while the RCEI did not, leading to higher estimated $\mathrm{HCl}$ emission in the RCEI. We estimated about $232.9 \mathrm{Gg} \mathrm{HCl}$ emission in China in 2012 in ACEIC, only about one-quarter of that estimated from the RCEI $(866.7 \mathrm{Gg})$. (4) The ACEIC accounts for $\mathrm{Cl}_{2}$ emission. The ACEIC includes $\mathrm{Cl}_{2}$ emission, which is also emitted during coal combustion in China based on the measurement by Deng et al. (2014).

In the following section, the ACEIC was incorporated into the CMAQ model to simulate the air quality in central and eastern China. It was evaluated by comparing the simulated and observed concentrations of chlorine species. In addition, the effect of chlorine emissions on tropospheric ozone formation was quantified to assess its importance in atmospheric chemistry in China. The refined and updated anthropogenic chlorine emission will help to evaluate the impact of chlorine emission on ozone formation in China.

\section{Impact of chlorine emissions on tropospheric ozone formation}

\subsection{Model setting}

The CMAQ model was developed by the United States Environmental Protection Agency (US EPA) to approach air quality as a whole by including state-of-the-science capabilities for modeling multiple air quality issues, including tropospheric ozone, fine particles, toxics, acid deposition, and visibility degradation (Byun and Schere, 2006). The latest version (5.1) was used in this study. Meteorological inputs were driven by the Weather Research and Forecasting (WRF) model. The meteorological boundary conditions and initial conditions of the WRF were provided by NCEP/NCAR final $(\mathrm{FNL})$ reanalysis data $\left(1^{\circ} \times 1^{\circ}\right)$. The modeling domain with $27 \mathrm{~km}$ horizontal resolution is shown in Fig. 3. The number of modeled layers was 40 and the highest layer can reach the top of $50 \mathrm{hPa}$. The CMAQ modeling domain covered central and eastern China, which was smaller than the WRF modeling domain, to reduce the effect of meteorological bound- 


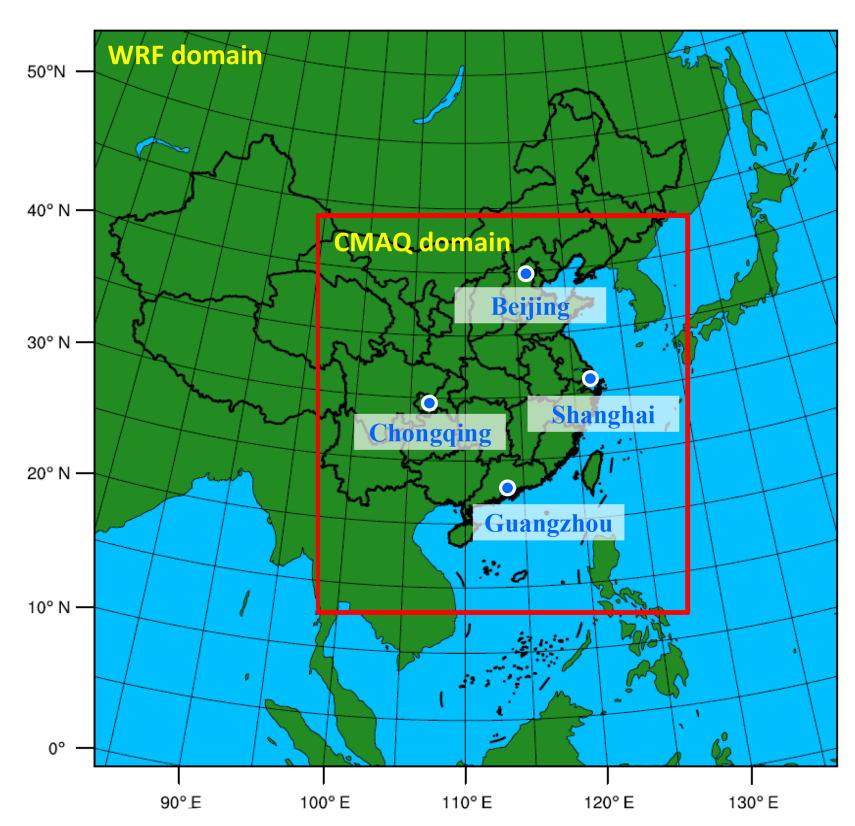

Figure 3. Modeling domain of WRF/CMAQ and the locations of typical sites: Beijing, Shanghai, Guangzhou, and Chongqing.

aries from the WRF model. The meteorology-chemistry interface processor (MCIP) was used to convert WRF outputs to CMAQ input format. The boundary conditions of chemical species for CMAQ were provided by the Model for Ozone and Related Chemical Tracers, version 4 (MOZART-4) results (http://www.acom.ucar.edu/wrf-chem/mozart.shtml).

In this study, anthropogenic and biogenic emissions were both included in the simulation. The MIX emission inventory (Li et al., 2017) was used in the simulation. International shipping emission was taken from the Hemispheric Transport Atmospheric Pollution (HTAP) emissions version 2.0 dataset (Janssens-Maenhout et al., 2015). Biogenic emission was calculated from the Model of Emissions of Gas and Aerosols from Nature (MEGAN) (Guenther et al., 2006). Additionally, sea salt emission was calculated during the simulation in the CMAQ model. The methods for estimating sea salt emission and its impact on aerosol chemical formation can be found in Liu et al. (2015). The SAPRC07TIC mechanism (Carter, 2010; Hutzell et al., 2012; Xie et al., 2013; Lin et al., 2013; Pye et al., 2015) was selected as the gas-phase chemical mechanism in the CMAQ model. ISORROPIA (Fountoukis and Nenes, 2007) was used to model the chemistry of inorganic aerosols. Detailed chlorine chemistry (including Eqs. 1-7) was considered in the CMAQ model.

The simulation was performed for November 2011. The spin-up time was 10 days (22-31 October) prior to November 2011. During the simulation period, China was controlled by high-pressure systems most of the time, which hindered the transport and diffusion of air pollutants.

Two experiments were set up to evaluate the impact of chlorine emission on tropospheric ozone formation. One ex- periment included the ACEIC in the model (Base experiment), while the other experiment did not ( $\mathrm{NoCl}$ experiment). The comparison of the Base and $\mathrm{NoCl}$ experiments could help to quantify the impacts of anthropogenic chlorine emissions. To include the ACEIC in the CMAQ model, the chlorine emissions from different economic sectors were temporally allocated in different ways. For the coal combustion from the power plant, industrial, and residential sectors, we distributed the total chlorine emissions between each month according to $\mathrm{Wu}$ (2009). In addition, the daily distributions of chlorine emissions from the power plant, industrial and residential sectors were allocated the same way as the allocations of the MIX inventory from the corresponding sectors. For the coal combustion from the other sectors, the total chlorine emission was divided equally into each month, each day, and each hour. Since the burning process of garbage disposal incinerators is similar to that of power plants, we assumed the same monthly and daily variation of prescribed waste incineration as that of the power plant sector. Four typical sites in four different regions were selected to analyze the diurnal variations of chlorine species: Beijing (BJ), Shanghai (SH), Guangzhou (GZ), and Chongqing (CQ). The locations of these sites are shown in Fig. 3.

\subsection{Evaluation of chlorine species}

\subsubsection{HCl evaluation}

Table 3 presents the comparison of modeled $\mathrm{HCl}$ concentrations to the observed values in China from available literature. It should be noted that the modeled and observed $\mathrm{HCl}$ concentrations were not paired in time and space. The modeled $\mathrm{HCl}$ concentrations in the $\mathrm{Base}$ and $\mathrm{NoCl}$ experiments in Beijing and Guangzhou were underestimated, while those in Shanghai and Hong Kong were overestimated. However, the modeled $\mathrm{HCl}$ concentrations from both experiments reasonably matched the observations in a similar magnitude. The difference between the modeled and observed $\mathrm{HCl}$ concentration in Beijing reduced when the ACEIC was incorporated into the model, implying the importance of anthropogenic emissions in this region.

\subsection{2 $\mathrm{Cl}_{2}$ evaluation}

Reports on $\mathrm{Cl}_{2}$ measurements in the atmosphere are sparse in the literature. The $\mathrm{Cl}_{2}$ concentration was measured to be about 2.3 pptv on average in La Jolla (Finley and Saltzman, 2008) and 2.5-20 pptv with a 2-month mean of 3.5 pptv in Irvine, California. We estimated a monthly average concentration of 1-10 pptv (most of urban regions) in China in this study by incorporating the ACEIC into the CMAQ system for air quality modeling (Fig. 6a), which was reasonable compared to the observed values in North America. $\mathrm{Cl}_{2}$ concentration was very low when anthropogenic chlorine emission was not included in the model (Fig. S8). 
Table 3. A comparison of predicted $\mathrm{HCl}$ concentrations for the Base and $\mathrm{NoCl}$ experiments to observed data from literature*

\begin{tabular}{llrrrl}
\hline Location & Period & Observation & Base & NoCl & Reference \\
\hline Beijing, China & Winter 2007 & 0.22 & 0.12 & 0.06 & Ianniello et al. (2011) \\
Beijing, China & Summer 2007 & 0.45 & & & Ianniello et al. (2011) \\
Beijing, China & Jul and Aug 2002 and 2003 & 0.6 & & & Wu et al. (2009) \\
Beijing, China & Jul-Aug 2001 & $0.3-0.8$ & & & Yao et al. (2003) \\
Shanghai, China & Oct-Nov 2012 & 0.5 & 0.87 & 0.64 & Shi et al. (2014) \\
Guangzhou, China & Oct-Nov 2004 & 2.8 & 1.10 & 1.05 & Hu et al. (2008) \\
Hong Kong & Autumn 2000 & 0.8 & 1.27 & 1.18 & Yao et al. (2006) \\
\hline
\end{tabular}

* Units are $\mu \mathrm{g} \mathrm{m}^{-3}$. Note that the observed and model values are not paired in time and space. Model predictions are taken from the general geographic areas of the observed data.

\subsection{3 $\mathrm{ClNO}_{2}$ evaluation}

The highest $\mathrm{ClNO}_{2}$ concentrations in China were observed throughout the Northern Hemisphere in the CMAQ simulation (Sarwar et al., 2014). Up to about 2000 pptv $\mathrm{ClNO}_{2}$ concentration was measured in Hong Kong during the summer of 2012 (Tham et al., 2014) and in Tianjin during the summer of 2014 (Tham et al., 2016). We estimated a monthly average concentration of up to 1178 pptv $\mathrm{ClNO}_{2}$ in China (Fig. 4g), which was comparable to the observed values.

\subsection{Impact of chlorine emission on atmospheric oxidation}

\subsubsection{Impact of $\mathrm{HCl}$ emission}

Figure 4a shows the spatial distribution of monthly average $\mathrm{HCl}$ concentration in the Base experiment. The $\mathrm{HCl}$ concentration over the ocean was higher than that over the land, due probably to the largest proportion of $\mathrm{HCl}$ emission from the dechlorination of sea salt aerosols (Graedel and Keene, 1995; Keene et al., 1999). The highest concentration of $\mathrm{HCl}$ was found in the South China Sea where sea salt emission was also high due to high wind speed and the downwind location (Fig. S4). The impact of chlorine emissions on $\mathrm{HCl}$ concentration is shown in Fig. $4 \mathrm{~b}$ and $\mathrm{c}$. The inclusion of the ACEIC in the model increased the $\mathrm{HCl}$ concentration by up to $1.7 \mu \mathrm{g} \mathrm{m}^{-3}$ in inland China. The chlorine emissions accounted for up to $85.6 \%$ of the $\mathrm{HCl}$ concentration in the Sichuan Basin (Fig. 4c). The dechlorination of sea salt aerosols transported to inland area was also considered an important proportion of $\mathrm{HCl}$ concentration, especially in South China and the coastal regions in East China (Fig. S5), where the impact of anthropogenic chlorine emission was low.

The spatial distribution of monthly mean concentrations of fine particulate $\mathrm{Cl}^{-}$is shown in Fig. 4d. A higher concentration was found in the North China Plain and the South China Sea. The concentrations of fine particulate $\mathrm{Cl}^{-}$increased by up to $2.0 \mu \mathrm{g} \mathrm{m}^{-3}$ when anthropogenic chlorine emissions were included in the model (Fig. 4e). The increase of fine particulate $\mathrm{Cl}^{-}$concentration was attributed to the gas-particle partitioning process of $\mathrm{HCl}$ and was sensitive to chlorine emissions, especially in the Sichuan Basin, contributing up to an $89 \%$ increase (Fig. 4 f).

The $\mathrm{HCl}$ concentrations were found to significantly increase in regions such as the Sichuan Basin and the YRD, consistent with the high anthropogenic chlorine emissions shown in Fig. 1a. However, the increase of $\mathrm{HCl}$ concentration was negligible in the North China Plain even though there was also high $\mathrm{HCl}$ emission, while surprisingly the concentration of particulate $\mathrm{Cl}^{-}$increased more significantly than that in the Sichuan Basin and the YRD. Volatile acidic species (i.e., $\mathrm{HCl}$ ) can be partitioned into particles by neutralization reactions (Seinfeld and Pandis, 1998). Chlorine partitioning between gas and particle phases $\left(\left[\mathrm{Cl}^{-}\right] /\left(\left[\mathrm{Cl}^{-}\right]+\right.\right.$ $[\mathrm{HCl}])$ ) was calculated and shown in Fig. 5. Higher chlorine partitioning meant that more $\mathrm{HCl}$ was transferred into particulate $\mathrm{Cl}^{-}$. The spatial distribution of chlorine partitioning in the Base and $\mathrm{NoCl}$ experiment was almost the same, suggesting that the chlorine emissions had little impact on the rate of gas-particle conversion. Higher chlorine partitioning rates were found in the North China Plain than in other regions in inland China, where $\mathrm{NH}_{3}$ emission was high (Fig. S6), leading to a significant increase of particulate $\mathrm{Cl}^{-}$concentration when the ACEIC was included in the model. Meanwhile, semi-volatile $\mathrm{NH}_{4} \mathrm{Cl}$ is formed via a reversible phase equilibrium with $\mathrm{NH}_{3}$ and $\mathrm{HCl}$ (Pio and Harrison, 1987). When the $\mathrm{HCl}$ emission was included in the model, $\mathrm{HCl}$ reacts with $\mathrm{NH}_{3}$ to produce particulate $\mathrm{NH}_{4}^{+}$and $\mathrm{Cl}^{-}$, provided that the $\mathrm{NH}_{3}$ emission was sufficiently high. High $\mathrm{NH}_{3}$ emission in the North China Plain accelerated the gas-particle transformation from $\mathrm{NH}_{3}$ to particulate $\mathrm{NH}_{4}^{+}$, leading to a decrease of $\mathrm{NH}_{3}$ concentration and an increase of $\mathrm{NH}_{4}^{+}$concentration in $\mathrm{PM}_{2.5}$ (up to -1.1 and $1.0 \mu \mathrm{g} \mathrm{m}^{-3}$, respectively) (Fig. S7).

The spatial distribution of daily maximum $1 \mathrm{~h} \mathrm{ClNO} 2$ concentration is shown in Fig. 4g. The $\mathrm{ClNO}_{2}$ concentration in the North China Plain, the Sichuan Basin, and the coastline along South China were significantly higher than those in other regions. The reservoir species $\mathrm{ClNO}_{2}$ was formed through the heterogeneous reaction between $\mathrm{Cl}^{-}$and $\mathrm{N}_{2} \mathrm{O}_{5}$ on the aerosol surfaces. High $\mathrm{Cl}^{-}$concentrations would 

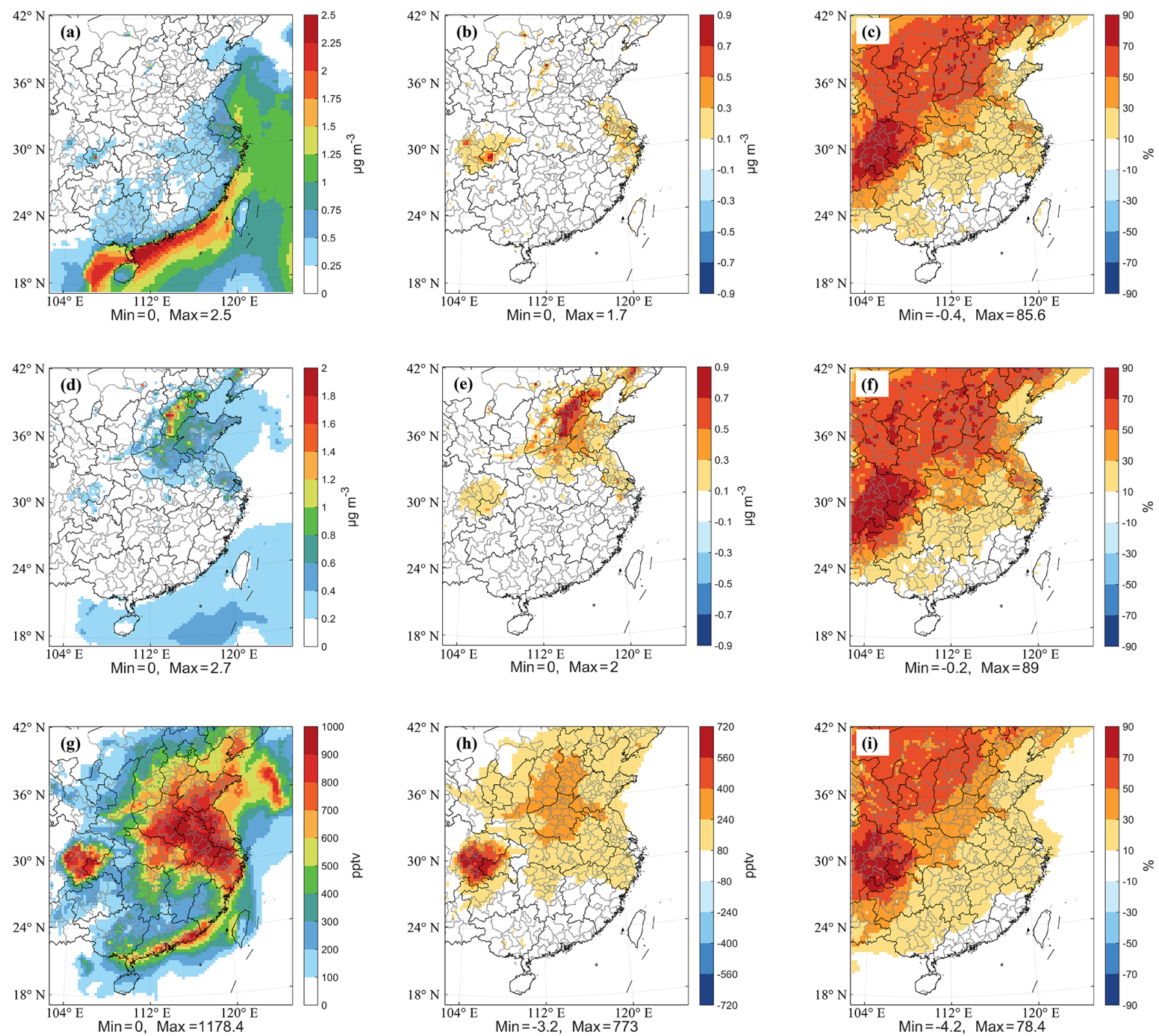

Figure 4. Spatial distributions of modeled $\mathrm{HCl}(\mathbf{a})$, fine particulate $\mathrm{Cl}^{-}$(d), and daily maximum $1 \mathrm{~h} \mathrm{ClNO}_{2}$ (g) average concentrations in November 2011 in the Base experiment; the differences (Base minus $\mathrm{NoCl}$ ) of modeled $\mathrm{HCl}$ (b), fine particulate $\mathrm{Cl}^{-}(\mathbf{e})$, and daily maximum $1 \mathrm{~h} \mathrm{ClNO}_{2}$ (h) average concentrations in November 2011; the percent changes of the $\mathrm{NoCl}$ experiment to the Base experiment of modeled $\mathrm{HCl}$ (c), fine particulate $\mathrm{Cl}^{-}$(f), and daily maximum $1 \mathrm{~h} \mathrm{ClNO}$ (i) average concentrations in November 2011.

accelerate the heterogeneous reaction rates, leading to enhanced $\mathrm{ClNO}_{2}$ production. The inclusion of the ACEIC in the model increased the monthly daily maximum $1 \mathrm{~h} \mathrm{ClNO}$ concentration by up to $773 \mathrm{pptv}$ in the whole domain, especially in the North China Plain and Sichuan Basin (Fig. 4h), highlighting the importance of anthropogenic chlorine emissions in $\mathrm{ClNO}_{2}$ formation (up to $78.4 \%$ of $\mathrm{ClNO}_{2}$ production was related to anthropogenic chlorine emissions) (Fig. 4i).

\subsubsection{Impact of $\mathrm{Cl}_{2}$ emission}

The spatial distribution of the monthly mean $\mathrm{Cl}_{2}$ concentration is presented in Fig. 6a. As expected, high concentrations were found in regions with high $\mathrm{Cl}_{2}$ emissions, including the Sichuan Basin, the YRD, and the North China Plain (Fig. 1b). The $\mathrm{Cl}_{2}$ concentration was very low $\left(<3.4 \times 10^{-3}\right.$ pptv $)$ when anthropogenic chlorine emissions were not included in the model (Fig. S8). The differences between Base and NoCl experiments (Fig. 6b) showed that $\mathrm{Cl}_{2}$ was almost all from direct emissions; nearly $100 \%$ of $\mathrm{Cl}_{2}$ was originated from inland anthropogenic chlorine emissions (Fig. 6c). The 

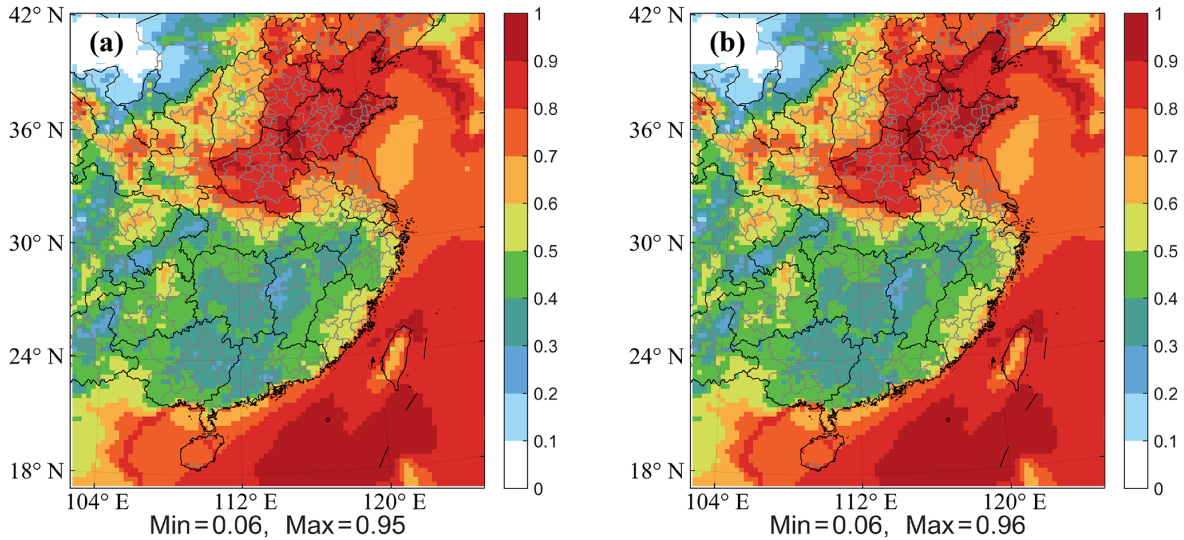

Figure 5. Spatial distribution of the monthly mean of chlorine partitioning $\left(\left[\mathrm{Cl}^{-}\right] /\left(\left[\mathrm{Cl}^{-}\right]+[\mathrm{HCl}]\right)\right)$ in the $\mathrm{Base}(\mathbf{a})$ and $\mathrm{NoCl}(\mathbf{b})$ experiment.
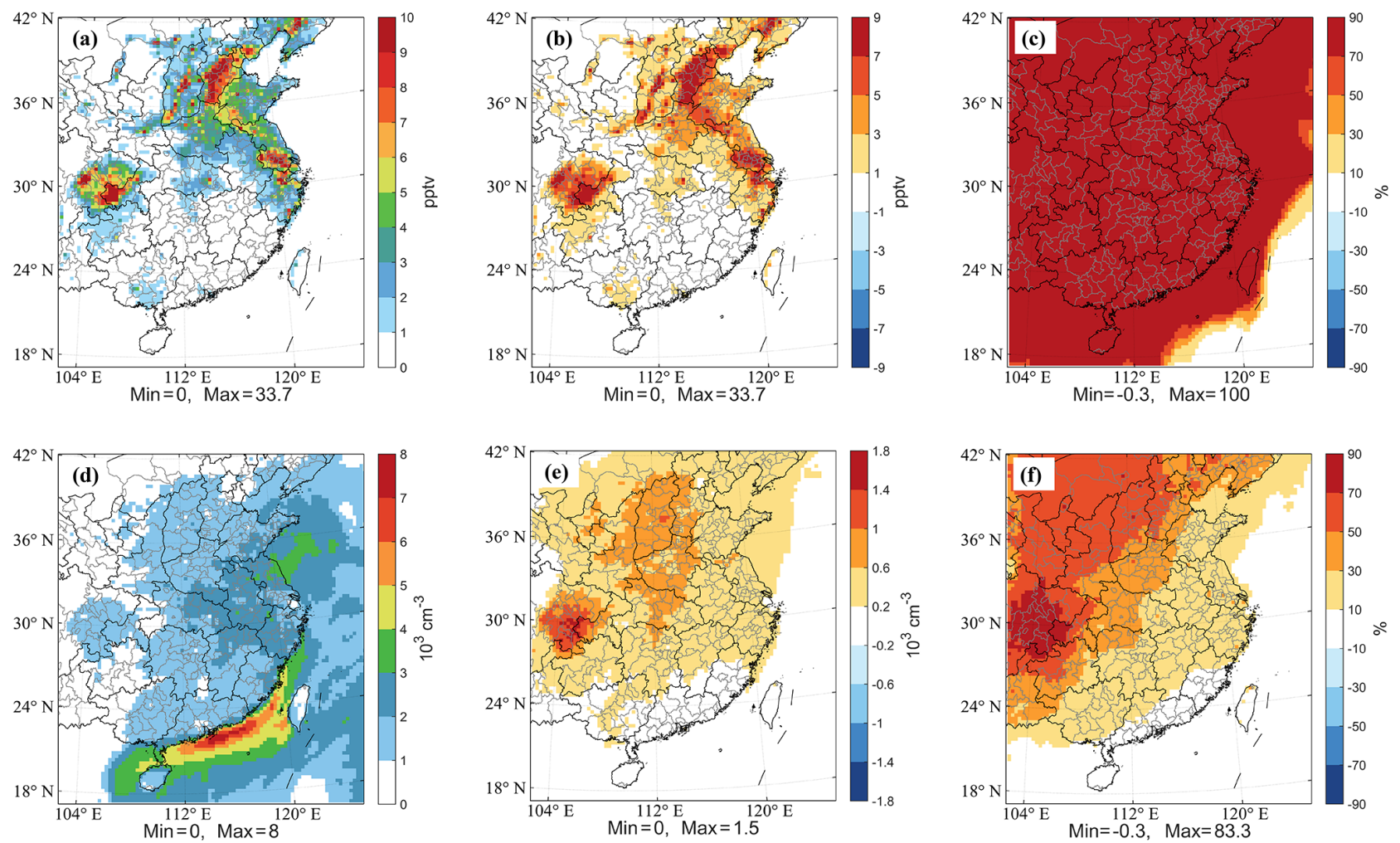

Figure 6. Spatial distributions of modeled $\mathrm{Cl}_{2}$ (a) and $\mathrm{Cl}$ radical (d) average concentrations in November 2011 in the Base experiment; the differences (Base minus $\mathrm{NoCl}$ ) of modeled $\mathrm{Cl}_{2}$ (b) and $\mathrm{Cl}$ radical (e) average concentrations in November 2011; the percent changes of the $\mathrm{NoCl}$ experiment to the Base experiment of modeled $\mathrm{Cl}_{2}$ (c) and $\mathrm{Cl}$ radical (f) average concentrations in November 2011.

results suggested that anthropogenic chlorine emission was a significant source of $\mathrm{Cl}_{2}$, which should be included in air quality modeling in order to accurately model regional air quality.

\subsubsection{Impact on Cl radicals}

Both $\mathrm{ClNO}_{2}$ (mainly from the heterogeneous reaction between particulate $\mathrm{Cl}^{-}$and $\mathrm{N}_{2} \mathrm{O}_{5}$ ) and $\mathrm{Cl}_{2}$ (mainly from di- rect emissions) can photolyze to produce $\mathrm{Cl}$ radicals after sunrise (Eqs. 1 and 2). The diurnal variation of $\mathrm{ClNO}_{2}, \mathrm{Cl}_{2}$, and $\mathrm{Cl}$ radicals is presented in Fig. 7. The $\mathrm{ClNO}_{2}$ concentration continued to drop and reached a minimal value between 12:00 and 16:00 but gradually increased after sunset due to the ceasing of photolysis and continuous accumulation of $\mathrm{ClNO}_{2}$ from the heterogeneous reaction, and then it reached a peak just before sunrise. The $\mathrm{Cl}_{2}$ concentration reached a 


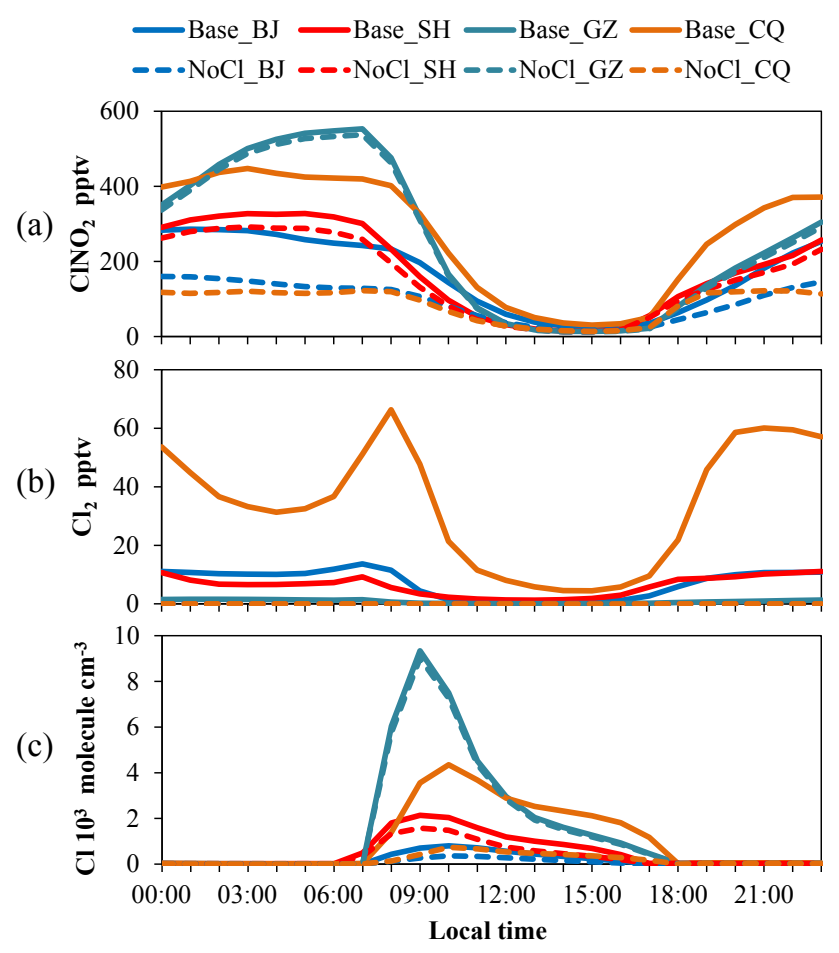

Figure 7. Diurnal variations of monthly mean concentrations of $\mathrm{ClNO}_{2}$ (a), $\mathrm{Cl}_{2}$ (b), and $\mathrm{Cl}$ radicals (c) in Beijing, Shanghai, Guangzhou, and Chongqing in the Base and $\mathrm{NoCl}$ experiments.

peak at about 08:00 and subsequently dropped substantially in the whole morning and early afternoon until 16:00 due to apparently photolysis. $\mathrm{The}_{2} \mathrm{Cl}_{2}$ concentration increased gradually after 16:00 and continued to accumulate during nighttime. The $\mathrm{Cl}$ radical concentration peaked in the morning due to the photolysis of $\mathrm{Cl}_{2}$ and $\mathrm{ClNO}_{2}$, while it was mainly formed through the reaction of $\mathrm{HCl}$ with $\mathrm{OH}$ in the afternoon when $\mathrm{Cl}_{2}$ and $\mathrm{ClNO}_{2}$ concentrations were very low. Similar diurnal cycles can be found at all sites; however, the impact of anthropogenic chlorine emissions at each site varied. Guangzhou and Shanghai sites could represent the coastal region, where the predominant sources of chlorine were from sea salt emission, while the Chongqing site could represent the inland region, where the predominant sources of chlorine were from coal combustion and waste incineration. The impact of anthropogenic chlorine emissions in Chongqing was higher than those in other regions.

The spatial distribution of $\mathrm{Cl}$ radical concentration is shown in Fig. 6d. A higher $\mathrm{Cl}$ radical concentration was found in the South China Sea, where high $\mathrm{HCl}$ concentration was found (Fig. S4a). The concentration of $\mathrm{Cl}$ radicals over the land reached up to $8 \times 10^{3}$ molecule $\mathrm{cm}^{-3}$. The $\mathrm{Cl}$ concentrations increased by up to $1.5 \times 10^{3}$ molecule $\mathrm{cm}^{-3}$ in the whole domain when anthropogenic chlorine emissions were considered in the model (Fig. 6e). The chlorine emission contributed up to $83.3 \%$ of $\mathrm{Cl}$ concentration (Fig. 6f).

\subsection{Impact of chlorine emissions on tropospheric ozone formation}

Atmospheric oxidation of VOCs initiated by the $\mathrm{Cl}$ radicals plays an important role in tropospheric ozone formation. The oxidation reaction was accelerated as the $\mathrm{Cl}$ concentration increased, leading to an increase of ozone and $\mathrm{OH}$ radical concentration. The $\mathrm{OH}$ radicals can in turn oxidize $\mathrm{NO}_{x}$ to produce particulate $\mathrm{NO}_{3}^{-}$, resulting in the decrease of $\mathrm{NO}_{x}$ concentration. The monthly mean daily maximum $8 \mathrm{~h} \mathrm{O}_{3}$ concentration was high in South China, the Sichuan Basin, and southwestern China during November 2011 and increased by up to $2.0 \mathrm{ppbv}(4.1 \%)$ when anthropogenic chlorine emission was included (Fig. 8a-c), especially in central China. It is also shown that the impact of chlorine emission on $1 \mathrm{~h}$ $\mathrm{O}_{3}$ concentration (Fig. S9) was similar to that of $8 \mathrm{~h} \mathrm{O}_{3}$. The impact of ACEIC was reasonable compared to the result reported in the Houston area (up to $3 \mathrm{ppbv}$ increase of $1 \mathrm{~h} \mathrm{O} 3$ concentration) by Sarwar and Bhave (2007). The $\mathrm{NO}_{x}$ concentration was observed to be high in the North China Plain (Fig. 8d). It slightly decreased by up to $0.5 \mathrm{ppbv}(6.1 \%)$ when the anthropogenic chlorine emissions were included in the model (Fig. 8e-f). In particular, regions such as the North China Plain and the Sichuan Basin were significantly affected by the chlorine emissions. The $\mathrm{NO}_{x}$ concentration decreased, corresponding to the increase of $\mathrm{O}_{3}$ concentration (Fig. $8 \mathrm{~b}$ and e). This is attributed to the fact that more ozone production leads to the release of $\mathrm{OH}$ radicals when chlorine emissions were included in the model, which results in more oxidation of $\mathrm{NO}_{x}$. The maximum impact of chlorine emissions on $1 \mathrm{~h} \mathrm{O} 3$ concentration is shown in Fig. 9. The largest increase of $1 \mathrm{~h} \mathrm{O}_{3}$ concentration was found along the Yangtze River, where the chlorine emission potentially increased the $1 \mathrm{~h} \mathrm{O}_{3}$ concentration by up to $7.7 \mathrm{ppbv}$.

\section{Conclusions}

The ACEIC was developed for the first time, which included $\mathrm{HCl}$ and $\mathrm{Cl}_{2}$ from coal combustion and prescribed waste incineration. The $\mathrm{HCl}$ and $\mathrm{Cl}_{2}$ emissions from coal combustion in China in 2012 were estimated to be 232.9 and $9.4 \mathrm{Gg}$, respectively, while $\mathrm{HCl}$ emission from prescribed waste incineration in China was estimated to be $2.9 \mathrm{Gg}$. The highest emissions of $\mathrm{HCl}$ and $\mathrm{Cl}_{2}$ were found in the North China Plain, the Yangtze River Delta, and the Sichuan Basin. In the ACEIC, $\mathrm{HCl}$ emissions from coal combustion of industry contributed $68 \%$ of the total emission, followed by others, residential, power plants, and prescribed waste incineration.

The modeling results with the ACEIC showed that the simulated $\mathrm{HCl}, \mathrm{Cl}_{2}$, and $\mathrm{ClNO}_{2}$ agreed reasonably with the observed values. The inclusion of anthropogenic chlorine emissions in the model increased the concentration of fine particulate $\mathrm{Cl}^{-}$, leading to an enhanced heterogeneous reaction of $\mathrm{Cl}^{-}$with $\mathrm{N}_{2} \mathrm{O}_{5}$, which produced $\mathrm{ClNO}_{2}$. Reaction of $\mathrm{HCl}$ 

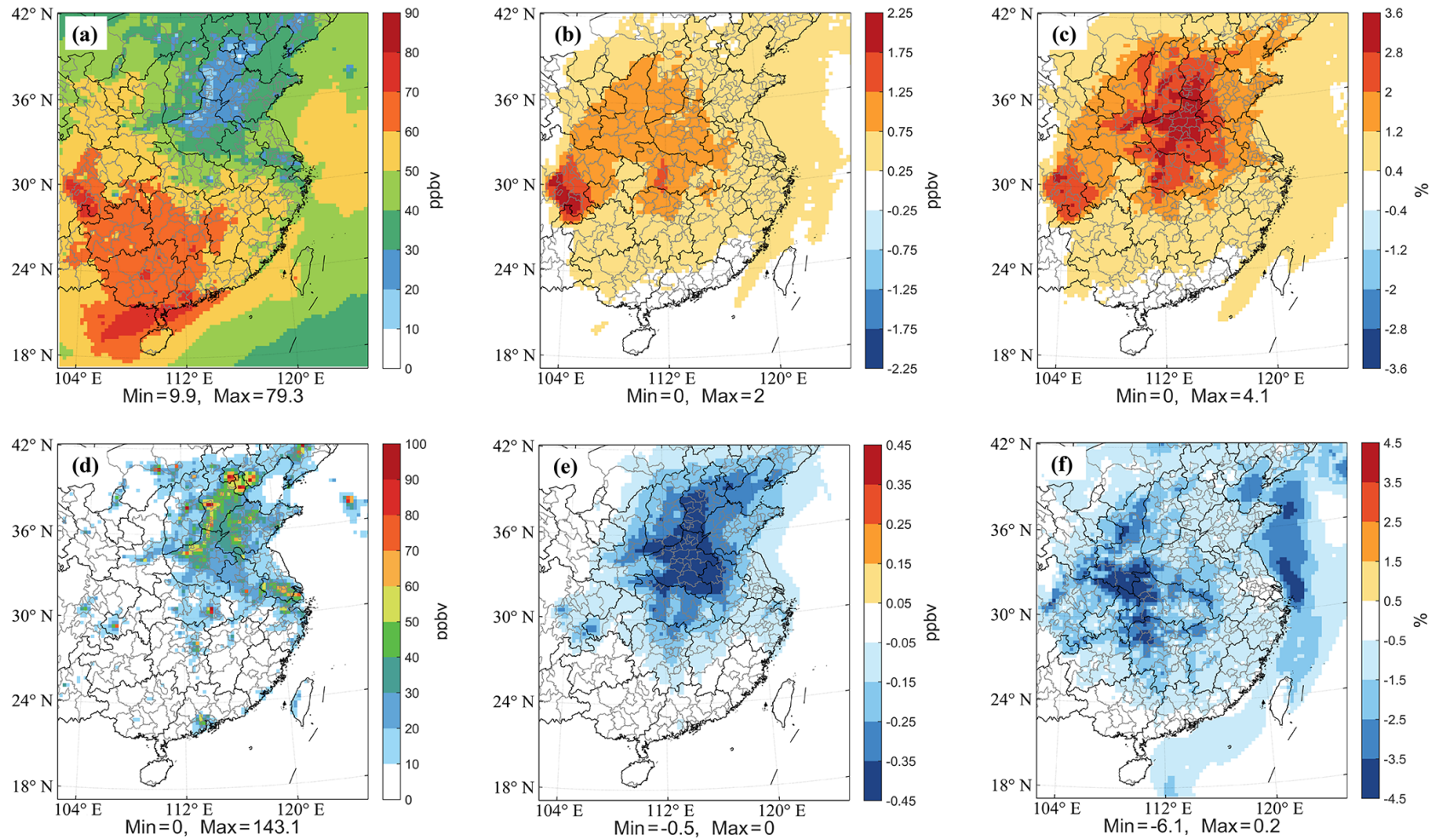

Figure 8. Spatial distributions of modeled daily maximum $8 \mathrm{~h} \mathrm{O} \mathrm{O}_{3}$ (a) and $\mathrm{NO}_{x}$ (d) average concentrations in November 2011 in the Base experiment; the differences (Base minus $\mathrm{NoCl}$ ) of modeled daily maximum $8 \mathrm{~h} \mathrm{O}$ (b) and $\mathrm{NO}_{x}$ (e) average concentrations in November 2011; the percent changes of the Base experiment to the $\mathrm{NoCl}$ experiment of modeled daily maximum $8 \mathrm{~h} \mathrm{O}_{3}$ (c) and $\mathrm{NO}_{x}$ (f) average concentrations in November 2011.

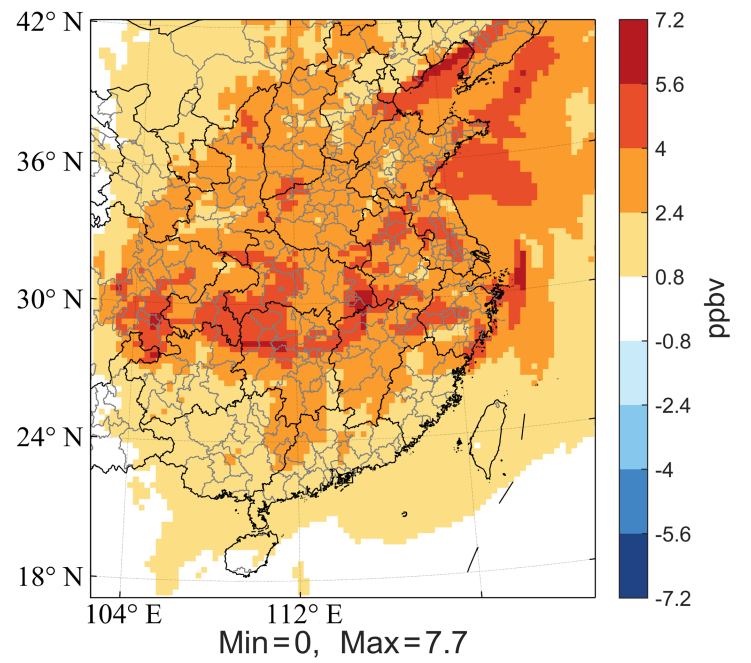

Figure 9. Spatial distribution of the maximum impact of chlorine emissions on $1 \mathrm{~h} \mathrm{O}_{3}$ concentration in November 2011.

with $\mathrm{OH}$ and photolysis of $\mathrm{ClNO}_{2}$ and $\mathrm{Cl}_{2}$ produce chlorine radicals. The monthly mean concentrations of fine particulate $\mathrm{Cl}^{-}$, daily maximum $1 \mathrm{~h} \mathrm{ClNO}_{2}$, and $\mathrm{Cl}$ radicals increased by up to $2.0 \mu \mathrm{g} \mathrm{m}^{-3}, 773 \mathrm{pptv}$, and $1.5 \times 10^{3}$ molecule $\mathrm{cm}^{-3}$ when anthropogenic chlorine emission was included in the model. In inland China, up to $89,78.4$, and $83.3 \%$ of monthly mean concentrations of fine particulate $\mathrm{Cl}^{-}$, daily maximum $1 \mathrm{~h} \mathrm{ClNO}_{2}$, and $\mathrm{Cl}$ radicals came from anthropogenic chlorine emissions, respectively.

The $\mathrm{Cl}$ radicals reacted with VOCs and potentially enhanced $\mathrm{O}_{3}$ concentration. The monthly mean concentration of daily maximum $8 \mathrm{~h} \mathrm{O}_{3}$ increased by up to $2.0 \mathrm{ppbv}(4.1 \%)$ when the ACEIC was included in the model. The chlorine emission potentially increased the $1 \mathrm{~h} \mathrm{O}_{3}$ concentration by up to $7.7 \mathrm{ppbv}$ in China. As the precursor of $\mathrm{O}_{3}$, the monthly mean concentration of $\mathrm{NO}_{x}$ decreased by up to $0.5 \mathrm{ppbv}$ $(6.1 \%)$. A significant increase of daily maximum $1 \mathrm{~h} \mathrm{O}_{3}$ was found in central China, corresponding to the region with a significant decrease of $\mathrm{NO}_{x}$.

More attention should be paid to the influence of chlorine emissions. The impact of chlorine emissions on ozone formation might vary from season to season. In the future, other typical months will be simulated and analyzed. In addition, emissions of hydrogen chloride and molecular chlorine not only contribute to the increase of tropospheric ozone concentration, but they also enhance the concentrations of particulate $\mathrm{NH}_{4}^{+}$. Further studies should focus on the impact of 
chlorine emissions on secondary aerosol formation and deposition.

Data availability. The datasets used in the study can be accessed from websites listed in the references or by contacting the corresponding author.

\section{The Supplement related to this article is available online at https://doi.org/10.5194/acp-18-2709-2018-supplement.}

Competing interests. The authors declare that they have no conflict of interest.

Acknowledgements. This work was supported by the National Key Research and Development Program of China (2017YFC0210105, 2016YFC0202206), the National Natural Science Foundation of China (NSFC) (91544102, 91644225, 21577177), the Science and Technology Planning Project of Guangdong Province, China (2014B020216003, 2016B050502005, 2014A020216008), the Science and Technology Planning Project of China (2014BAC21B02), and the National Key Research and Development Program of China (2016YFC0203600). This work was also partly supported by the Jiangsu Collaborative Innovation Center for Climate Change and the high-performance grid-computing platform of Sun Yat-sen University. The authors acknowledge Qiang Zhang of Tsinghua University for sharing the MIX inventory.

Edited by: Andrea Pozzer

Reviewed by: two anonymous referees

\section{References}

Andreae, M. O., Atlas, E., Harris, G. W., Helas, G., de Koc, A., Koppmann, R., Maenhaut, W., Manø, S., Pollock, W. H., Rudolph, J., Scharffe, D., Schebeske, G., and Welling, M.: Methyl halide emissions from savanna fires in southern Africa, J. Geophys. Res., 101, 23603-23613, https://doi.org/10.1029/95JD01733, 1996

Aschmann, S. M. and Atkinson, R.: Rate constants for the gas-phase reactions of alkanes with $\mathrm{Cl}$ atoms at $296 \pm 2 \mathrm{~K}$, Int. J. Chem. Kinet., 27, 613-622, https://doi.org/10.1002/kin.550270611, 1995.

Bertram, T. H. and Thornton, J. A.: Toward a general parameterization of $\mathrm{N}_{2} \mathrm{O}_{5}$ reactivity on aqueous particles: the competing effects of particle liquid water, nitrate and chloride, Atmos. Chem. Phys., 9, 8351-8363, https://doi.org/10.5194/acp-9-8351-2009, 2009.

Byun, D. W. and Schere, K. L.: Review of the Governing Equations, Computational Algorithms, and Other Components of the Models-3 Community Multiscale Air Quality (CMAQ) Modeling System, Appl. Mech. Rev., 59, 51-77, https://doi.org/10.1115/1.2128636, 2006.
Carter, W. P. L.: Development of the SAPRC-07 chemical mechanism, Atmos. Environ., 44, 5324-5335, https://doi.org/10.1016/j.atmosenv.2010.01.026, 2010.

Chang, S. H. and Allen, D. T.: Atmospheric chlorine chemistry in southeast Texas: Impacts on ozone formation and control, Environ. Sci. Technol., 40, 251-262, https://doi.org/10.1021/es050787z, 2006.

Chang, S. H., McDonald-Buller, E., Kimura, Y., Yarwood, G., Neece, J., Russell, M., Tanaka, P., and Allen, D.: Sensitivity of urban ozone formation to chlorine emission estimates, Atmos. Environ., 36, 4991-5003, https://doi.org/10.1016/S13522310(02)00573-3, 2002.

Chen, L. H.: Study on environmental geochemistry of chlorine in Chinese coals, M.S. thesis, Nanchang University, China, 46 pp., 2010.

Deng, S., Zhang, C., Liu, Y., Cao, Q., Xu, Y. Y., Wang, H. L., and Zhang, F.: A full-scale field study on chlorine emission of pulverized coal-fired power plants in China, Res. Environ. Sci., 27, 127-133, https://doi.org/10.13198/j.issn.1001-6929.2014.02.03, 2014 (in Chinese).

Emmel, T. E., Waddell, J. T., and Adams, R. C.: Acidic emissions control technology and costs, Pollution Technology Review, 168. NC, USA, Radian Corporation, 155 pp., 1989.

Faxon, C. B. and Allen, D. T.: Chlorine chemistry in urban atmospheres: a review, Environ. Chem., 10, 221-233, https://doi.org/10.1071/EN13026, 2013.

Finley, B. D. and Saltzman, E. S.: Observations of $\mathrm{Cl}_{2}, \mathrm{Br}_{2}$, and $\mathrm{I}_{2}$ in coastal marine air, J. Geophys. Res.-Atmos., 113, D21301, https://doi.org/10.1029/2008JD010269, 2008.

Fountoukis, C. and Nenes, A.: ISORROPIA II: a computationally efficient thermodynamic equilibrium model for $\mathrm{K}^{+}$$\mathrm{Ca}^{2+}-\mathrm{Mg}^{2+}-\mathrm{NH}_{4}^{+}-\mathrm{Na}^{+}-\mathrm{SO}_{4}^{2-}-\mathrm{NO}_{3}^{-}-\mathrm{Cl}^{-}-\mathrm{H}_{2} \mathrm{O}$ aerosols, Atmos. Chem. Phys., 7, 4639-4659, https://doi.org/10.5194/acp-74639-2007, 2007.

Graedel, T. E. and Keene, W. C.: Tropospheric budget of reactive chlorine, Global Biogeochem. Cy., 9, 47-77, https://doi.org/10.1029/94GB03103, 1995.

Guenther, A., Karl, T., Harley, P., Wiedinmyer, C., Palmer, P. I., and Geron, C.: Estimates of global terrestrial isoprene emissions using MEGAN (Model of Emissions of Gases and Aerosols from Nature), Atmos. Chem. Phys., 6, 3181-3210, https://doi.org/10.5194/acp-6-3181-2006, 2006.

Hu, M., Wu, Z. J., Slanina, J., Lin, P., Liu, S., and Zeng, L. M.: Acidic gases, ammonia and water-soluble ions in $\mathrm{PM}_{2.5}$ at a coastal site in the Pearl River Delta, China, Atmos. Environ., 42, 6310-6320, https://doi.org/10.1016/j.atmosenv.2008.02.015, 2008.

Hutzell, W. T., Luecken, D. J., Appel, K. W., and Carter, W. P. L.: Interpreting predictions from the SAPRC07 mechanism based on regional and continental simulations, Atmos. Environ., 46, 417429, https://doi.org/10.1016/j.atmosenv.2011.09.030, 2012.

Ianniello, A., Spataro, F., Esposito, G., Allegrini, I., Hu, M., and Zhu, T.: Chemical characteristics of inorganic ammonium salts in $\mathrm{PM}_{2.5}$ in the atmosphere of Beijing (China), Atmos. Chem. Phys., 11, 10803-10822, https://doi.org/10.5194/acp-11-108032011, 2011.

Iapalucci, T. L., Demski, R. J., and Bienstock, D.: Chlorine in coal combustion, US Bureau of Mines, Report of Investigations, USBMRI7260, Pittsburgh, USA, vp., 1969. 
IEA (International Energy Agency): Energy Statistics of OECD countries and non-OECD countries, IEA, Paris, available at http: //www.iea.org/statistics (last access: February 2018), 2012.

Impey, G. A., Shepson, P. B., Hastie, D. R., and Barrie, L. A.: Measurement technique for the determination of photolyzable chlorine and bromine in the atmosphere, J. Geophys. Res., 102, 15999-16004, https://doi.org/10.1029/97JD00850, 1997.

Janssens-Maenhout, G., Crippa, M., Guizzardi, D., Dentener, F., Muntean, M., Pouliot, G., Keating, T., Zhang, Q., Kurokawa, J., Wankmüller, R., Denier van der Gon, H., Kuenen, J. J. P., Klimont, Z., Frost, G., Darras, S., Koffi, B., and Li, M.: HTAP_v2.2: a mosaic of regional and global emission grid maps for 2008 and 2010 to study hemispheric transport of air pollution, Atmos. Chem. Phys., 15, 11411-11432, https://doi.org/10.5194/acp-15-11411-2015, 2015.

Jiang, J. K., Hao, J. M., Wu, Y., David, G. S., Duan, L., and Tian, H. Z.: Development of mercury emission inventory from coal combustion in China, Environ. Sci., 26, 34-39, https://doi.org/10.13227/j.hjkx.2005.02.007, 2005 (in Chinese).

Jiang, X. G., Li, X. P., Li, Q., Chi, C., and Yan, J. H.: Industrial experiment study on chloride emission and dechlorination technology, Thermal Power Generation, 2004, 37-39, 2004 (in Chinese).

Keene, W. C., Khalil, M. A. K., Erickson, D. J., McCulloch, A., Graedel, T. E., Lobert, J. M., Aucott, M. L., Gong, S. L., Harper, D. B., and Kleiman, G.: Composite global emissions of reactive chlorine from anthropogenic and natural sources: Reactive Chlorine Emission Inventory, J. Geophys. Res.-Atmos., 104, 84298440, https://doi.org/10.1029/1998JD100084, 1999.

Lawler, M. J., Sander, R., Carpenter, L. J., Lee, J. D., von Glasow, R., Sommariva, R., and Saltzman, E. S.: $\mathrm{HOCl}$ and $\mathrm{Cl}_{2}$ observations in marine air, Atmos. Chem. Phys., 11, 7617-7628, https://doi.org/10.5194/acp-11-7617-2011, 2011.

Lightowlers, P. J. and Cape, J. N.: Sources and fate of atmospheric $\mathrm{HCl}$ in the UK and western Europe, Atmos. Environ., 22, 7-15, https://doi.org/10.1016/0004-6981(88)90294-6, 1988.

Li, M., Zhang, Q., Kurokawa, J.-I., Woo, J.-H., He, K., Lu, Z., Ohara, T., Song, Y., Streets, D. G., Carmichael, G. R., Cheng, Y., Hong, C., Huo, H., Jiang, X., Kang, S., Liu, F., Su, H., and Zheng, B.: MIX: a mosaic Asian anthropogenic emission inventory under the international collaboration framework of the MICS-Asia and HTAP, Atmos. Chem. Phys., 17, 935-963, https://doi.org/10.5194/acp-17-935-2017, 2017.

Li, Q., Zhang, L., Wang, T., Tham, Y. J., Ahmadov, R., Xue, L., Zhang, Q., and Zheng, J.: Impacts of heterogeneous uptake of dinitrogen pentoxide and chlorine activation on ozone and reactive nitrogen partitioning: improvement and application of the WRF-Chem model in southern China, Atmos. Chem. Phys., 16, 14875-14890, https://doi.org/10.5194/acp-16-148752016, 2016.

Lin, Y. H., Zhang, H., Pye, H. O. T., Zhang, Z., Marth, W. J., Park, S., Arashiro, M., Cui, T., Budisulistiorini, S. H., Sexton, K.G., Vizuete, W., Xie, Y., Luecken, D. J., Piletic, I. R., Edney, E. O., Bartolotti, L. J., Gold, A., and Surratt, J. D.: Epoxide as a precursor to secondary organic aerosol formation from isoprene photooxidation in the presence of nitrogen oxides, P. Natl. Acad. Sci. USA, 110, 6718-6723, https://doi.org/10.1073/pnas.1221150110, 2013.
Liu, Y. M., Zhang, S. T., Fan, Q., Wu, D., Chan, P. W., Fan, S. J., Feng, Y. R., and Hong, Y. Y.: Accessing the impact of seasalt emissions on aerosol chemical formation and deposition over Pearl River Delta, China, Aerosol Air Qual. Res., 15, 2232-2245, https://doi.org/10.4209/aaqr.2015.02.0127, 2015.

Lobert, J. M., Keene, W. C., Logan, J. A., and Yevich, R.: Global chlorine emissions from biomass burning: Reactive Chlorine Emissions Inventory, J. Geophys. Res.-Atmos., 104, 8373-8389, https://doi.org/10.1029/1998JD100077, 1999.

Lopez-Vilarino, J. M., Fernandez-Martinez, G., Turnes-Carou, I., Muniategui-Lorenzo, S., Lopez-Mahia, P., and PradaRodriguez, D.: Behavior of fluorine and chlorine in Spanish coal fired power plants with pulverized coal boilers and fluidized bed boiler, Environ. Technol., 24, 687-692, https://doi.org/10.1080/09593330309385604, 2003.

$\mathrm{Lu}, \mathrm{B}$. H.: Occurrence characteristics of fluorine and chlorine in coal seam in China, Coal Geology and Exploration, 24, 9-12, 1996 (in Chinese).

McCulloch, A., Aucott, M. L., Benkovitz, C. M., Graedel, T. E., Kleiman, G., Midgley, P. M., and Li, Y. F.: Global emissions of hydrogen chloride and chloromethane from coal combustion, incineration and industrial activities: Reactive Chlorine Emissions Inventory, J. Geophys. Res.-Atmos., 104, 8391-8403, https://doi.org/10.1029/1999JD900025, 1999.

Mei, H. S., Chen, D. Z., Liu, Y., and Mao, Q. X.: Incineration flue gas purification in a laboratory scale cyclone scrubber, Journal of Tongji University (Natural Science), 34, 953-959, 2006 (in Chinese).

National Bureau of Statistics: China Urban-Rural Construction Statistical Yearbook 2012, China Statistics Press, Beijing, 2012.

National Bureau of Statistics: China Energy Statistical Yearbook 2013, China Statistics Press, Beijing, 2013.

Nelson, L., Rattigan, O., Neavyn, R., Sidebottom, W., Treacy, J., and Nielsen, O. J.: Absolute and relative rate constants for the reactions of hydroxyl radicals and chlorine atoms with a series of aliphatic alchohols and ethers at 298K, Int. J. Chem. Kinet., 22, 1111-1126, https://doi.org/10.1002/kin.550221102, 1990.

Pio, C. A. and Harrison, R. M.: Vapour pressure of ammonium chloride aerosol: effect of temperature and humidity, Atmos. Environ., 21, 2711-2715, https://doi.org/10.1016/00046981(87)90203-4, 1987.

Pye, H. O. T., Luecken, D. J., Xu, L., Boyd, C. M., Ng, N. L., Baker, K., Ayres, B. A., Bash, J. O., Baumann, K., Carter, W. P. L., Edgerton, E., Fry, J. L., Hutzell, W. T., Schwede, D., and Shepson, P. B.: Modeling the current and future roles of particulate organic nitrates in the southeastern United States, Environ. Sci. Technol., 49, 14195-14203, https://doi.org/10.1021/acs.est.5b03738, 2015.

Riedel, T. P., Bertram, T. H., Crisp, T. Q., Williams, E. J., Lerner, B. M., Vlasenko, A., Li, S. M., Gilman, J., de Gouw, J., Bon, D. M., Wagner, N. L., Brown, S. S., and Thornton, J. A.: Nitryl chloride and molecular chlorine in the coastal marine boundary layer, Environ. Sci. Technol., 46, 10463-10470, https://doi.org/10.1021/es204632r, 2012.

Robert, J. M., Osthoff, H. D., Brown, S. S., Ravishankara, A. R., Coffman, D., Quinn, P., and Bates, T.: Laboratory studies of products of $\mathrm{N}_{2} \mathrm{O}_{5}$ uptake on $\mathrm{Cl}^{-}$containing substrates, Geophys. Res. Lett., 36, L20808, https://doi.org/10.1029/2009GL040448, 2009. 
Sarwar, G. and Bhave, P. V.: Modeling the effect of chlorine emissions on ozone levels over the eastern United States, J. Appl. Meteorol. Clim., 46, 1009-1019, https://doi.org/10.1175/JAM2519.1, 2007.

Sarwar, G., Simon, H., Xing, J., and Mathur, R.: Importance of tropospheric $\mathrm{ClNO}_{2}$ chemistry across the Northern Hemisphere, Geophys. Res. Lett., 41, 4050-4058, https://doi.org/10.1002/2014GL059962, 2014.

Seinfeld, J. H. and Pandis, S. N.: Atmospheric Chemistry and Physics, John Wiley \& Sons, Inc., New York, 1998.

Shi, Y., Chen, J. M., Hu, D. W., Wang, L., Yang, X., and Wang, X. M.: Airborne submicron particulate $\left(\mathrm{PM}_{1}\right)$ pollution in Shanghai, China: Chemical variability, formation/dissociation of associated semi-volatile components and the impacts on visibility, Sci. Total Environ., 473, 199-206, https://doi.org/10.1016/j.scitotenv.2013.12.024, 2014.

Spicer, C. W., Plastridge, R. A., Foster, K. L., Finlayson-Pitts, B. J., Bottenheim, J. W., Grannas, A. M., and Shepson, P. B.: Molecular halogens before and during ozone depletion events in the Arctic at polar sunrise: concentrations and sources, Atmos. Environ., 36, 2721-2731, https://doi.org/10.1016/S1352-2310(02)001255, 2002.

Tang, X. Y. and Chen, P.: Chlorine in coal of China, Coal Geology of China, 14, 33-36, 2002 (in Chinese).

Tham, Y. J., Yan, C., Xue, L. K., Zha, Q. Z., Wang, X. F., and Wang, T.: Presence of high nitryl chloride in Asian coastal environment and its impact on atmospheric photochemistry, Chinese Sci. Bull., 59, 356-359, https://doi.org/10.1007/s11434-013-0063-y, 2014.

Tham, Y. J., Wang, Z., Li, Q., Yun, H., Wang, W., Wang, X., Xue, L., Lu, K., Ma, N., Bohn, B., Li, X., Kecorius, S., Größ, J., Shao, M., Wiedensohler, A., Zhang, Y., and Wang, T.: Significant concentrations of nitryl chloride sustained in the morning: investigations of the causes and impacts on ozone production in a polluted region of northern China, Atmos. Chem. Phys., 16, 14959-14977, https://doi.org/10.5194/acp-16-14959-2016, 2016.

Wang, L., Arey, J., and Atkinson, R.: Reactions of chlorine atoms with a series of aromatic hydrocarbons, Environ. Sci. Technol., 39, 5302-5310, https://doi.org/10.1021/es0479437, 2005.

Wiedinmyer, C., Yokelson, R. J., and Gullett, B. K.: Global emissions of trace gases, particulate matter, and hazardous air pollutants from open burning of domestic waste, Environ. Sci. Technol., 48, 9523-9530, https://doi.org/10.1021/es502250z, 2014.
Wingenter, O. W., Blake, D. R., Blake, N. J., Sive, B. C., Rowland, F. S., Atlas, E., and Flocke, F.: Tropospheric hydroxyl and atomic chlorine concentrations, and mixing timescales determined from hydrocarbon and halocarbon measurements made over the Southern Ocean, J. Geophys. Res.-Atmos., 104, 21819 21828, https://doi.org/10.1029/1999JD900203, 1999.

$\mathrm{Wu}, \mathrm{X}$. L.: The study of air pollution emission inventory in Yangtze Delta, M.S. thesis, Fudan University, China, 94 pp., 2009.

$\mathrm{Wu}$, Z. J., Hu, M., Shao, K. S., and Slanina, J.: Acidic gases, $\mathrm{NH}_{3}$ and secondary inorganic ions in $\mathrm{PM}_{10}$ during summertime in Beijing, China and their relation to air mass history, Chemosphere, 76, 1028-1035, https://doi.org/10.1016/j.chemosphere.2009.04.066, 2009.

Xie, Y., Paulot, F., Carter, W. P. L., Nolte, C. G., Luecken, D. J., Hutzell, W. T., Wennberg, P. O., Cohen, R. C., and Pinder, R. W.: Understanding the impact of recent advances in isoprene photooxidation on simulations of regional air quality, Atmos. Chem. Phys., 13, 8439-8455, https://doi.org/10.5194/acp13-8439-2013, 2013.

Yao, X. H., Lau, A. P. S., Fang, M., Chan, C. K., and Hu, M.: Size distributions and formation of ionic species in atmospheric particulate pollutants in Beijing, China: 1 - inorganic ions, Atmos. Environ., 37, 2991-3000, https://doi.org/10.1016/S13522310(03)00255-3, 2003.

Yao, X. H., Ling, T. Y., Fang, M., and Chan, C. K.: Comparison of thermodynamic predictions for in situ $\mathrm{pH}$ in $\mathrm{PM}_{2.5}$, Atmos. Environ., 40, 2835-2844, https://doi.org/10.1016/j.atmosenv.2006.01.006, 2006.

Young, C. J., Washenfelder, R. A., Edwards, P. M., Parrish, D. D., Gilman, J. B., Kuster, W. C., Mielke, L. H., Osthoff, H. D., Tsai, C., Pikelnaya, O., Stutz, J., Veres, P. R., Roberts, J. M., Griffith, S., Dusanter, S., Stevens, P. S., Flynn, J., Grossberg, N., Lefer, B., Holloway, J. S., Peischl, J., Ryerson, T. B., Atlas, E. L., Blake, D. R., and Brown, S. S.: Chlorine as a primary radical: evaluation of methods to understand its role in initiation of oxidative cycles, Atmos. Chem. Phys., 14, 3427-3440, https://doi.org/10.5194/acp-14-3427-2014, 2014.

Zhao, F. H., Ren, D. Y., and Wang, Z.: Geochemical characteristics and step-by-step extraction of chlorine in coal, Journal of China University of Mining and Technology, 28, 61-64, 1999 (in Chinese). 